This PDF is a selection from an out-of-print volume from the National Bureau of Economic Research

Volume Title: The Political Economy of American Trade Policy

Volume Author/Editor: Anne O. Krueger, ed.

Volume Publisher: University of Chicago Press

Volume ISBN: 0-226-45489-4

Volume URL: http://www.nber.org/books/krue96-1

Conference Date: February 3-4, 1994

Publication Date: January 1996

Chapter Title: Agricultural Interest Groups and the North American Free Trade Agreement

Chapter Author: David Orden

Chapter URL: http://www.nber.org/chapters/c8709

Chapter pages in book: (p. 335 - 384) 


\title{
7 \\ Agricultural Interest Groups and the North American Free Trade Agreement
}

\author{
David Orden
}

During 1993 a shrill public debate over the North American Free Trade Agreement (NAFTA) took place in the United States. The idea of negotiating one or more bilateral free trade agreements (FTAs) had initially been raised by the Reagan administration in the early 1980s. The dual intent of proposing these agreements was to lower barriers to trade with important U.S. economic partners and to build pressure for multilateral reforms under the General Agreement on Tariffs and Trade (GATT). After a delay of several years, an Israel-U.S. agreement developed relatively quickly and was approved by Congress in May 1985. The multilateral Uruguay Round GATT negotiations were launched subsequently (September 1986), and a bilateral agreement with Canada was approved in September 1988.

Mexico proposed developing a FTA with the United States in May 1990. The GATT negotiations were stalled, but entering into a bilateral trade agreement with Mexico was more controversial than the previous agreements with Israel and Canada. Nevertheless, the United States embraced negotiations, which were expanded to include Canada in 1991. A trilateral agreement was reached in August 1992 and was signed by the three heads of state in December.

With the change in administration early in 1993, newly elected President Clinton sought supplementary (side) agreements to clarify and strengthen the original provisions of NAFTA with respect to environmental protection, labor

David Orden is associate professor of agricultural and applied economics at Virginia Polytechnic Institute and State University.

The author thanks Barbara Craig, Carol Goodloe, and Anne Krueger and other participants in the NBER's conference on the political economy of trade protection for helpful comments on an earlier version of this paper. He is also indebted to the many parties to the NAFTA debate who shared their insights in interviews and other correspondence, and to Nicole Fatseas, Laura Zepp, and the staff of the Senate Committee on Agriculture, Nutrition and Forestry for their assistance. 
rights, and mechanisms to protect domestic producers from unanticipated import surges. Negotiations for these side-agreements were completed in August. Still facing substantial domestic opposition to NAFTA, the Clinton administration then launched an intense campaign for passage of the implementing legislation. It won a crucial and surprisingly large come-from-behind victory with a majority of Republican support when the House of Representatives approved the bill on November 17 by a 234-200 vote. This decision set the stage for concluding efforts on the multilateral GATT negotiations in December 1993, and NAFTA took effect January 1, 1994.

This paper focuses on the attempts of U.S. agricultural interest groups to influence the outcomes of both the negotiations for NAFTA and the congressional debate over its implementing legislation. The objectives of the analysis are to investigate the goals and strategies of different interest groups and to evaluate the success of their efforts either to have NAFTA create expanded export opportunities or to limit the scope of the agreement in order to retain existing protection. Agricultural issues have loomed large in world trade discussions since the inception of the Uruguay Round GATT negotiations, and Canada and Mexico are important agricultural trade partners of the United States; they account jointly for more than one-fourth of U.S. agricultural imports and one-sixth of U.S. agricultural exports. For these reasons, the agricultural provisions of NAFTA became an important component of the agreement. Moreover, agricultural interests ultimately played a crucial role in the coalition that supported the NAFTA implementing legislation.

More specifically, the agricultural commodity groups became aligned as supporters of trade liberalization under NAFTA or as proponents of limits on the scope of the agreement based on their particular interests in trade with Mexico and Canada and their perceptions of NAFTA's broader implications. Early in the negotiations, the various groups confronted a high-level decision by Mexico and the United States to include all agricultural products under provisions for long-run liberalization. The U.S. agricultural groups supporting trade liberalization had some influence on this decision, but it was more widely attributed to willingness of Mexico to remove trade barriers from its politically sensitive and historically highly protected corn sector.

Under the negotiated agreement announced in August 1992, all licenses and quotas restricting Mexico-U.S. agricultural trade were to be converted to tariffs in January 1994. These and other tariffs were also to be completely phased out over adjustment periods of up to 15 years. Canada had resisted such full coverage of the agricultural provisions of NAFTA, and the U.S. agricultural groups and others favoring liberalized trade had not been able to extract Canadian concessions. Instead, it had been agreed that pending modification by an Uruguay Round GATT agreement, the less comprehensive Canada-U.S. FTA, which left nontariff barriers intact for dairy, poultry, and other sectors, would remain in effect for bilateral Canada-U.S. trade. Mexico and Canada had negotiated a similar agreement. 
Because NAFTA promised to liberalize U.S. agricultural trade with Mexico, the agreement as negotiated received support in the United States from marketoriented general-membership farm organizations and from most exportoriented producers of grains, oilseeds, livestock, and some horticultural products. The dairy and cotton sectors, although protected by U.S. import quotas, joined the NAFTA supporters when it became apparent that Mexico had little capacity to produce competitive imports and strong rules of origin were adopted.

The NAFTA negotiations and the August 1992 agreement were opposed by farm groups favoring restrictive supply controls to raise domestic prices, wheat producers seeking leverage on Canadian export subsidy issues, and protected sugar, peanut, and citrus and other winter fruit and vegetable producers objecting to specific transition-period provisions. The presidential election in November 1992 appeared to open renewed opportunities for influence by these groups, but the side-agreements negotiated by the new Clinton administration were limited in scope. Dissatisfied with these results, the producer groups opposed to various NAFTA provisions sought further accommodations in the subsequent legislative debate. Willingness to withdraw their opposition in exchange for specific concessions gave them substantial bargaining power relative to organized labor and others committed to the defeat of the NAFTA implementing legislation.

As the heavily contested congressional vote approached in November 1993, critical support for the implementing legislation from agricultural interest groups (or at least the withdrawal of their active opposition) came at the expense of some weakening of the original agreement and other related costs. Concessions made to agricultural interests protected U.S. sugar from Mexican competition, provided some transition-period protection to winter fruits and vegetables, and ensnared the United States in disputes about Canadian exports of wheat and peanut butter. While the long-run provisions for agricultural trade liberalization remained intact, with the final concessions NAFTA results in essentially no reform of entrenched domestic agricultural support programs in the United States (or Canada) during the lengthy tariff phase-out periods. Thus, those interests favoring more open trade can only be judged partially successful in their efforts and, likewise, the NAFTA process only partially successful in expanding international market opportunities, at least for the next 10 to 15 years.

To develop these themes, this paper is organized as follows. Section 7.1 provides a brief description of U.S. agricultural production, trade, and price support policies as a basis for evaluating the stakes of various interest groups in NAFTA. Section 7.2 examines the initial positions of the agricultural interest groups and their strategies for influencing the negotiations. Next, the provisions of the negotiated agreement are summarized and public and private sector assessments of these provisions are reviewed. The focus then turns to the side-agreements negotiated by the Clinton administration, the activities of 
the various agricultural interest groups during the congressional debate over the implementing legislation, and the final concessions and guarantees offered to obtain support for the legislation from agricultural interests. The concluding section addresses some issues raised by the NAFTA outcomes for agriculture.

\subsection{Diversity within Agriculture}

From an aggregate perspective, agriculture represents less than 3 percent of national output. Even so, agricultural production is diffused among many diverse sectors. Descriptive statistics about production, aggregate trade, and bilateral trade with Canada and Mexico at the outset of the NAFTA negotiations (1989-91 averages) are presented for the major groups of commodities in table 7.1.

Grains and oilseeds accounted for one-fifth of the value of U.S. production of agricultural commodities and their direct products during 1989-91. Grains and oilseeds are generally exported crops, with one-fourth of the value of production sold in world markets and the percentage as high as 60 to 75 percent for wheat and rice. Imports of grains and oilseeds are minimal but imports from Canada comprised over one-third of their value, and essentially all of the value of imported wheat, barley, and soybeans.

Livestock and poultry products accounted for another one-fifth of the value of domestic agricultural production during 1989-91. The United States has maintained some quantitative meat import restrictions, and trade has been less important for livestock and poultry products than for grains and oilseeds. The value of imports and the value of exports of livestock and poultry products were less than 5 percent, respectively, of the value of domestic production. Of this trade, Canada produced over 35 percent of U.S. import value and Mexico another 10 percent. Canada and Mexico each accounted for over 15 percent of the value of U.S. exports.

A third group of commodities important in the context of NAFTA are those for which the United States has traditionally imposed import quotas under section 22 of the Agricultural Adjustment Act of 1935 and its extensions. The section 22 legislation authorized trade restrictions when imports "render ineffective or materially interfere with" domestic supply control and price support programs of the U.S. Department of Agriculture (USDA). Dairy products, cotton, and peanuts are among the commodities for which there have been section 22 quotas. Imports of these commodities have been restricted to less than 2 percent of domestic production. Exports of dairy products were also less than 2 percent of domestic production at the beginning of the NAFTA negotiations, but exports accounted for more than 40 percent of U.S. cotton and 15 percent of the value of peanut production. ${ }^{1}$ Mexico received over one-third of the U.S.

1. Dairy products are priced above world levels in domestic markets and are exported with subsidies, while the price support mechanisms for cotton facilitate exports at most times despite 
U.S. Production and Trade of Agricultural Products, 1989-91 Averages

\begin{tabular}{|c|c|c|c|c|c|c|c|c|c|c|c|c|c|}
\hline \multirow[b]{3}{*}{ Commodity } & \multirow[b]{3}{*}{ Production $^{\mathrm{a}}$} & \multicolumn{6}{|c|}{ U.S. Imports } & \multicolumn{6}{|c|}{ U.S. Exports } \\
\hline & & \multicolumn{2}{|c|}{ Total } & \multicolumn{2}{|c|}{ Canada } & \multicolumn{2}{|c|}{ Mexico } & \multicolumn{2}{|c|}{ Total } & \multicolumn{2}{|c|}{ Canada } & \multicolumn{2}{|c|}{ Mexico } \\
\hline & & Amount $^{a}$ & $\begin{array}{c}\text { Percentage } \\
\text { of } \\
\text { Production }\end{array}$ & Amount ${ }^{a}$ & $\begin{array}{c}\text { Percentage } \\
\text { of } \\
\text { Total } \\
\text { Imports }\end{array}$ & Amount ${ }^{a}$ & $\begin{array}{c}\text { Percentage } \\
\text { of } \\
\text { Total } \\
\text { Imports }\end{array}$ & Amount ${ }^{a}$ & $\begin{array}{c}\text { Percentage } \\
\text { of } \\
\text { Production }\end{array}$ & Amount ${ }^{a}$ & $\begin{array}{c}\text { Percentage } \\
\text { of } \\
\text { Total } \\
\text { Exports }\end{array}$ & Amount $^{a}$ & $\begin{array}{c}\text { Percentage } \\
\text { of } \\
\text { Total } \\
\text { Exports }\end{array}$ \\
\hline Grains and oilseeds & 86,633 & 1,669 & 1.93 & 646 & 38.71 & 45 & 2.70 & 20,993 & 24.23 & 595 & 2.83 & 1,445 & 6.88 \\
\hline $\begin{array}{l}\text { Livestock and } \\
\text { poultry }\end{array}$ & 85,520 & 3,510 & 4.10 & 1,245 & 35.47 & 358 & 10.20 & 2,974 & 3.48 & 505 & 16.98 & 476 & 16.01 \\
\hline \multicolumn{14}{|c|}{ Section 22 commodities } \\
\hline Dairy products & 43,932 & 808 & 1.84 & 15 & 1.86 & $<.05$ & $<.05$ & 324 & .74 & 18 & 5.55 & 123 & 37.96 \\
\hline Cotton & 4,627 & 4 & .09 & $<.05$ & 1.25 & .70 & 17.50 & 1,856 & 40.11 & 67 & 3.61 & 50 & 2.69 \\
\hline Peanuts & 1,260 & 11 & .87 & 4 & 36.37 & $<.05$ & $<.05$ & 209 & 16.59 & 40 & 19.14 & 7 & 3.35 \\
\hline Sugar & 4,574 & 669 & 14.63 & 14 & 2.09 & 13 & 1.94 & 183 & 4.00 & 25 & 13.66 & 82 & 44.81 \\
\hline $\begin{array}{l}\text { Sugar-containing } \\
\text { products }\end{array}$ & 53,203 & 1,325 & 2.49 & 357 & 26.94 & 73 & 5.51 & 1,643 & 3.09 & 447 & 27.20 & 115 & 7.00 \\
\hline \multicolumn{14}{|l|}{ Horticultural } \\
\hline Vegetables $^{b}$ & 18,540 & 1,270 & 6.85 & 170 & 13.39 & 343 & 27.00 & 1,468 & 7.92 & 481 & 32.77 & 100 & 6.81 \\
\hline Winter vegetables & 1,290 & 563 & 43.64 & 11 & 1.95 & 523 & 92.89 & 127 & 9.84 & 121 & 95.27 & 3 & 2.36 \\
\hline Citrus juices & 1,154 & 482 & 41.76 & 1 & $<.05$ & 66 & 13.69 & 203 & 17.59 & 79 & 38.92 & $<.05$ & $<.05$ \\
\hline Other fruits ${ }^{\mathfrak{c}}$ & 9,279 & 2,315 & 24.95 & 62 & 2.68 & 300 & 12.96 & 1,883 & 20.29 & 559 & 29.69 & 43 & 2.28 \\
\hline Subtotal & 310,012 & 12,626 & 4.07 & 2,525 & 20.00 & 1,722 & 13.64 & 31,863 & 10.28 & 2,937 & 9.22 & 2,444 & 7.67 \\
\hline Other & 83,539 & 14,131 & 16.91 & 1,768 & 12.51 & 768 & 5.43 & 9,536 & 11.40 & 1,213 & 12.72 & 331 & 3.47 \\
\hline Total & 393,551 & 26,757 & 6.80 & 4,293 & 16.04 & 2,490 & 9.30 & 41,399 & 10.52 & 4,150 & 10.02 & 2,775 & 6.70 \\
\hline
\end{tabular}

Source: U.S. International Trade Commission (USITC 1993).

${ }^{a}$ In million dollars.

'Excludes winter vegetables.

'Includes citrus other than juices.

'Remaining categories (e.g., fish, wood, alcoholic beverages, cut flowers). 
dairy exports and provided one-sixth of the U.S. cotton imports. Canada provided almost one-third of the U.S. imports of peanuts and peanut products.

Historically, section 22 quotas on imports of sugar and sugar-containing products were also used to protect U.S. producers and give preferential treatment to selected foreign suppliers. Domestic production of cane and beet sugar has increased since 1980 under the most recent trade restrictions. High domestic sugar prices have also contributed to use of high-fructose corn sweeteners increasing from less than one-fourth of total caloric sweetener consumption in 1979-81 to almost one-half in 1989-91.

The U.S. sugar import quotas were challenged by Australia in 1989 under GATT rules because domestic supply controls were not in effect at that time. ${ }^{2}$ To settle the GATT dispute, the import quotas were replaced by a two-tier tariff regime. Under the two-tier tariffs, a limited quantity of imports, known as a tariff-rate quota (TRQ), enters under a low rate $(\$ 0.01 / \mathrm{lb})$. Potential additional imports carry an over-quota tariff of more than 80 percent $(\$ 0.18 / \mathrm{lb}$ ).

While in principle the two-tier sugar tariff regime allows access to the U.S. market in response to world market conditions, the over-quota tariffs have been prohibitive and the TRQ and two-tier tariffs have had trade restrictive effects similar to the previous quota system. To protect domestic producers, sugar imports have been reduced from over 3 million metric tons (MMT) in 1980 to less than 2 MMT-just under 15 percent of domestic production-during 1989-91. Mexico provided only a small fraction of U.S. imports of sugar and sugar-containing products. Canada provided over one-fourth of the sugarcontaining products that were imported.

A final group of agricultural commodities is composed of horticultural products. The bulk of domestic production is of vegetables for which imports or exports accounts for less than 10 percent of production value. Trade is more important for seasonal winter vegetables. For these commodities, imports were over 40 percent and exports were almost 10 percent of the value of domestic production during 1989-91. Over 90 percent of the imports came from Mexico, and over 90 percent of the exports went to Canada. Trade is also relatively important for citrus and other winter fruits. Citrus imports are primarily frozen concentrated orange juice from Brazil that competes with production in Florida. Citrus exports are mostly fresh products from California, with Canada an important export market. California fruit and vegetable producers and processors have also integrated their operations into Mexico to a greater extent than their Florida counterparts. Thus, the horticultural sector is characterized by divergent commodity, seasonal, and regional interests.

the section 22 quotas. Peanut exports arise from a two-tier pricing scheme that allows sales at lower world price levels of U.S. peanuts beyond a quantity produced for the domestic market.

2. Domestic production quotas were assigned in 1993 for the first time since Cuban sugar imports were proscribed after Fidel Castro took power in 1959. 


\begin{tabular}{|c|c|c|c|c|c|c|c|}
\hline \multirow[b]{3}{*}{ Commodity } & \multirow[b]{3}{*}{$\begin{array}{l}\text { Number of } \\
\text { Farms }\end{array}$} & \multicolumn{6}{|c|}{ Value of Farm Sales } \\
\hline & & \multicolumn{2}{|c|}{ Less than $\$ 50,000$} & \multicolumn{2}{|c|}{$\$ 50,000$ to $\$ 500,000$} & \multicolumn{2}{|c|}{ More than $\$ 500,000$} \\
\hline & & $\begin{array}{l}\text { Percentage of } \\
\text { Farms }\end{array}$ & $\begin{array}{c}\text { Percentage of } \\
\text { Production }\end{array}$ & $\begin{array}{c}\text { Percentage of } \\
\text { Farms }\end{array}$ & $\begin{array}{l}\text { Percentage of } \\
\text { Production }\end{array}$ & $\begin{array}{c}\text { Percentage of } \\
\text { Farms }\end{array}$ & $\begin{array}{l}\text { Percentage of } \\
\text { Production }\end{array}$ \\
\hline Grains and oilseeds & 407,503 & 61.14 & 15.08 & 37.80 & 74.18 & .75 & 10.73 \\
\hline \multicolumn{8}{|l|}{ Livestock and poultry } \\
\hline Beef cattle excluding feedlots & 626,366 & 89.67 & 26.53 & 9.76 & 44.00 & .56 & 29.45 \\
\hline Beef cattle feedlots & 65,888 & 73.98 & 2.37 & 20.98 & 12.49 & 5.03 & 85.14 \\
\hline Hogs & 93,256 & 57.52 & 9.94 & 40.64 & 69.82 & 1.83 & 20.24 \\
\hline Poultry and eggs & 36,410 & 17.62 & .46 & 65.36 & 37.17 & 12.70 & 62.36 \\
\hline \multicolumn{8}{|l|}{ Section 22 commodities } \\
\hline Dairy & 131,542 & 28.94 & 5.57 & 67.53 & 64.83 & 3.51 & 29.59 \\
\hline Cotton & 22,841 & 32.72 & 4.04 & 63.08 & 71.46 & 4.19 & 24.49 \\
\hline Sugar ${ }^{a}$ & 107,791 & 83.93 & 10.86 & 14.87 & 49.04 & 1.19 & 40.10 \\
\hline \multicolumn{8}{|l|}{ Horticultural } \\
\hline Vegetables and melons & 23,375 & 68.62 & 4.98 & 26.35 & 28.95 & 5.02 & 66.06 \\
\hline Fruits and tree nuts & 89,369 & 74.76 & 9.93 & 22.21 & 39.10 & 3.03 & 51.26 \\
\hline Other & 275,226 & 84.45 & 17.22 & 15.26 & 58.44 & 2.72 & 24.23 \\
\hline Total & $1,879,567$ & 72.94 & 10.84 & 25.43 & 50.86 & 1.62 & 38.29 \\
\hline
\end{tabular}

Source: U.S. Department of Commerce, Bureau of the Census, Census of Agriculture (Washington, D.C.: Government Printing Office, 1987).

alncludes sugarcane and sugar beets but also field crops other than grains and oilseeds for which there have not been any section 22 restrictions. 


\subsubsection{Farm Numbers}

Some characteristics of the different production sectors are summarized in table 7.2. Grains and oilseeds were produced on over 400,000 farms and beef cattle on over 625,000 farms and ranches. There were over 130,000 dairy farms, and just over 100,000 farms produced sugar or field crops other than grains and oilseeds. Less than 100,000 farms fattened cattle on feedlots, raised hogs, or produced fruits and tree nuts, respectively, while less than 50,000 farms produced poultry and eggs, cotton, or vegetables and melons.

Of the units counted as farms, almost three-fourths had gross sales of under $\$ 50,000$ and provided less than full-time employment for a farm operator. This type of farm produced less than 10 percent of the total value of output except in the cases of grains and oilseeds, beef cattle (excluding feedlots), and sugar and other field crops. In contrast, less than 2 percent of all farms had sales of $\$ 500,000$ and above. The farms in this sales class produced from 40 to 90 percent of the beef cattle on feedlots, poultry and eggs, sugar and other field crops, vegetables and melons, and fruits and tree nuts.

\subsubsection{Levels of Support and Protection}

There are differences among the sectors in terms of the level of support provided through domestic farm programs and the protection provided by trade policies. Producer subsidy equivalents (PSEs), shown in the first two columns of table 7.3, estimate the percentage of farm income derived from a wide range of policy interventions, including price policies, direct payments, trade barriers, and insurance, credit, tax, and other input and processing subsidies. Annual PSEs have been calculated by the Organisation for Economic Cooperation and Development (OECD) and USDA since the early 1980s. These estimates have been utilized as a basis for comparing agricultural policies among countries during negotiations of the GATT Uruguay Round, the Canada-U.S. FTA, and NAFTA.

The levels of protection provided to various commodities by tariffs and other border policies are also reported in table 7.3. The tariff rates in effect at the beginning of the NAFTA negotiations are shown in the third column. Estimates of the differences between domestic and world prices induced by tariffs and quantitative border restrictions are shown in the fourth column.

The PSEs and protection measures in table 7.3 show that U.S. policy interventions provide high levels of support for some export crops as well as for the commodities protected historically by import quotas. Support for export crops is provided primarily through acreage-reduction-based supply restrictions, direct payments to producers that supplement market returns, and floor prices ("loan rates") at which farmers can place their output in storage and receive a loan from the government. Wheat producers also benefit particularly from export subsidies. The PSEs have been higher for wheat, barley, and rice than for corn, oats, sorghum, and soybeans. Tariff levels are relatively low for all of the grains, reflecting the policies of domestic market prices near world levels and 


\begin{tabular}{|c|c|c|c|c|}
\hline \multirow[b]{2}{*}{ Commodity } & \multicolumn{2}{|c|}{$\begin{array}{l}\text { Producer Subsidy } \\
\text { Equivalents } \\
\text { (\% of domestic } \\
\text { prices) }\end{array}$} & \multicolumn{2}{|c|}{$\begin{array}{c}\text { Border Protection } \\
\text { (\% of international prices) }\end{array}$} \\
\hline & $1982-91$ & 1991 & 1991 Tariffs $^{a}$ & $\begin{array}{c}\text { Tariff } \\
\text { Equivalents }\end{array}$ \\
\hline \multicolumn{5}{|l|}{ Grains and oilseeds } \\
\hline Barley & 36 & 50.8 & $<2.5$ & 3.0 \\
\hline Corn & 28 & 16.8 & 0.6 & 2.0 \\
\hline Oats & 10 & 14.9 & 0.0 & 0.0 \\
\hline Rice & 47 & 39.7 & 6.5 & 8.0 \\
\hline Sorghum & 31 & 18.4 & 7.0 & 7.0 \\
\hline Wheat & 40 & 53.6 & 3.7 & 6.0 \\
\hline Durum wheat & - & - & 4.1 & 6.0 \\
\hline Soybeans & 8 & 16.5 & 0.0 & 0.0 \\
\hline Meal & - & - & $<5.0$ & $<5.0$ \\
\hline Oil & - & - & 22.5 & 22.5 \\
\hline Other edible oils & - & - & 18.5 & 18.5 \\
\hline \multicolumn{5}{|l|}{ Livestock and poultry } \\
\hline Beef and veal & 8 & 7.0 & $<5.0$ & 31.1 \\
\hline Pork & 6 & 5.9 & $<5.0$ & 2.0 \\
\hline Poultry & 9 & 7.3 & $<15.0$ & 16.3 \\
\hline \multicolumn{5}{|l|}{ Section 22 commodities } \\
\hline Dairy & 49 & 40.5 & & \\
\hline Butter & - & - & $<15.0$ & 95.7 \\
\hline Cheese & - & - & $<20.0$ & 69.5 \\
\hline Nonfat dry milk & - & - & $<5.6$ & 83.1 \\
\hline Cotton & - & - & $<5.0$ & 26.0 \\
\hline Peanuts & - & - & & \\
\hline Shelled & - & - & 16.1 & 186.1 \\
\hline Unshelled & - & - & 5.8 & 123.1 \\
\hline Peanut butter & - & - & $<5.0$ & 126.0 \\
\hline Sugar & 60 & 52.5 & $\mathrm{TRQ}^{\mathrm{c}}$ & 83.7 \\
\hline Sugar-containing products & - & - & Various & 120.3 \\
\hline \multicolumn{5}{|l|}{ Horticultural } \\
\hline \multicolumn{5}{|l|}{ Orange juice (frozen } \\
\hline Fruits and vegetables & - & - & & \\
\hline Cucumbers & - & - & $20.0-30.0$ & $20.0-30.0$ \\
\hline Melons & - & - & $10.0-20.0$ & $10.0-20.0$ \\
\hline Onions & - & - & $5.0-10.0$ & $5.0-10.0$ \\
\hline Peppers & - & - & $5.0-10.0$ & $5.0-10.0$ \\
\hline Tomatoes & - & - & $5.0-10.0$ & $5.0-10.0$ \\
\hline
\end{tabular}

Sources: PSEs are from USDA (1994); 1991 tariffs are from USDA (1992a); estimates of tariff equivalents of border protection are from Sanderson (1994) except for dairy products, cotton, and shelled and unshelled peanuts, which are from USDA (1992b).

Note: (-) Not available.

"Many tariffs are expressed at fixed rates, so ad valorem estimates vary with commodity prices. 'Estimated differences between domestic and world prices induced by various border restrictions. cTariff-rate quota (limited imports at low duty and prohibitive tariff for additional quantities). 
support through direct payments.

For the import-quota or TRQ-protected commodities dairy, peanuts, and sugar, large distortions favoring domestic producers have been created by the import restrictions, as shown by the estimated tariff equivalents of these barriers. Cotton producers, while protected by section 22 quotas, also receive direct payments, and U.S. prices are usually near world levels.

In contrast to the section 22 commodities or the principal grains and oilseeds, fruits and vegetables have not been subject to import quotas, and producers have received few direct support payments (PSEs are not available for fruits and vegetables). In general, producers of fruits and vegetables receive relatively low levels of protection from tariffs, but there are a few exceptions. The support and protection levels have also been relatively low for livestock and poultry. The estimated tariff equivalent for beef (31.1 percent) suggests that meat import restrictions have had more effect than indicated by the estimated PSEs but have been less severe than for the section 22 commodities.

The policy interventions in U.S. agriculture and the levels of support and protection provided to different commodities are the cumulative result of convoluted economic and political forces. In an empirical assessment, Gardner (1987), for example, found that support (measured similarly to the PSEs by the producer price gains resulting from farm programs) increased systematically across commodities when elasticities of supply and demand were low, a larger share of output was imported or exported, and the lagged level of total farm income declined relative to nonfarm income. Given these determinants of support, factors that facilitated political organization by a sector also were significant. There was a nonlinear relationship between the number of producers of a commodity and the level of support obtained, with less support of commodities for which there were either fewer or greater numbers of producers. Support also increased with the size of the average unit and with the geographic concentration of production and stability of its location over time.

Observations based on tables 7.1-7.3 corroborate several of Gardner's hypotheses and suggest a few others (see also Swinnen and van der Zee 1993, and the references therein). Most commodities produced domestically are protected from import competition. Among the exported commodities, levels of support are positively correlated with the degree of export dependence, although the direction of causality remains open to question. The high levels of support obtained by wheat and barley producers may be explained by the lack of alternative production opportunities (inelastic supply) in the dryer parts of the midwestern grain belt where these commodities are produced. Grains generally receive more support than oilseeds even though they are often grown on the same farms. This is a historical consequence of the origins of the support programs in the Depression-era policies of the New Deal when soybeans were not grown as a livestock feed on a commercial basis.

Among the factors affecting the relative demands for support and protection, the levels of intervention are higher for the moderate number of farms produc- 
ing grains or dairy than for either the large number of farms producing beef cattle or the relatively small number producing cattle on feedlots, poultry and eggs, cotton, or vegetables and melons. The extent of processing associated with the products from a sector also might be hypothesized to be related to the levels of support and protection. But dairy, sugar, and peanuts obtain high levels of protection and soybeans and beef cattle relatively low levels of support even though the products from each of these sectors requires substantial processing.

\subsection{Interest Group Approaches to the Negotiations}

Agricultural interests are represented both by general-membership organizations and by numerous commodity-based associations. The approaches of these various groups to the NAFTA negotiations were affected by specific aspects of bilateral trade with Mexico and Canada and the levels of support and protection received by producers, described above, and by their perceptions of NAFTA's relationship to other bilateral and multilateral trade agreements. A chronology of relevant events is shown in table 7.4.

When the Mexico-U.S. free trade negotiations were jointly announced, Mexico's President Carlos Salinas de Gortari and President Bush articulated a

Table 7.4

Early 1980 s

May 1985

September 1986

September 1988

April 1989

June 1990

May 1991

June 1991

August 1992

September 1992

October 1992

December 1992

March 1993

August 1993

September 1993

November 1993

December 1993

January 1994

\section{Chronology of NAFTA}

Free trade agreements with Israel, Canada, and Mexico contemplated by the Reagan administration

Israel-U.S. Free Trade Agreement approved by Congress

Ministerial declaration launched the Uruguay Round GATT negotiations

Canada-U.S. Free Trade Agreement approved by Congress

Midterm agreement reached for Uruguay Round negotiations on agriculture

President Bush and President Salinas issued a joint statement in support of negotiating a bilateral free trade agreement

Canada officially joined the trade negotiations with Mexico and the United States

NAFTA negotiations initiated

NAFTA negotiations concluded

President Bush announced to Congress his intent to sign the agreement

Presidential candidate Clinton announced his support for NAFTA if supplemental (side) agreements were negotiated to address issues of the environment, labor, and import surges

Leaders of Canada, Mexico, and the United States signed NAFTA in their respective capitals

Negotiations on side-agreements initiated

Negotiations on side-agreements concluded

President Clinton signed the side-agreements and began an intense campaign for passage of the implementing legislation

NAFTA legislation approved by Congress

Uruguay Round GATT negotiations concluded

NAFTA went into effect 
broad mandate for reducing trade barriers and supporting Mexican reforms in agriculture and other sectors. In particular, bilateral trade had been affected by the high levels of protection that Mexican agriculture had received in the mid1980s: PSEs had averaged 47.6 percent among 14 major commodities (USDA 1994). Under reforms initiated by the administration of President Salinas, the average Mexican PSE had declined to 19.9 percent by 1990. Concurrently, the value of U.S. agricultural exports to Mexico increased from $\$ 1.2$ billion to $\$ 2.5$ billion.

The growth of agricultural exports stimulated commodity group interest in the United States in further development of trade opportunities. Even so, and despite the reforms initiated by the Salinas administration, the high levels of protection traditionally provided to many commodities in both countries created considerable uncertainty about the extent to which agriculture would be included under the mandate for Mexico-U.S. trade liberalization.

The uncertainty about agriculture increased when Canada joined Mexico and the United States in seeking a trilateral agreement. Nontariff agricultural trade barriers had not been addressed in the previous Canada-U.S. FTA (see, e.g., Miner 1993). Import restrictions were retained by Canada to protect its dairy and poultry sectors, which benefited in 1991 from PSEs of 67.0 and 35.0 percent, respectively, and by the United States for dairy, cotton, peanuts, and sugar. Although both the Canadian and the U.S. wheat producers sought agreements to bar unfair domestic and export subsidies, because of differences in their support and marketing systems finding mutually acceptable definitions remained elusive for these highly subsidized and export-dependent competitors. Canada retained import licensing authority for grains unless U.S. PSEs fell below Canadian levels, and little progress was made on mutual commitments to develop rules governing subsidies. Both countries retained the right to reintroduce either quotas or tariffs on grains if "imports increase significantly as a result of a substantial change in either Party's support programs."

There was also uncertainty with respect to NAFTA's agricultural provisions because the negotiations took place against the backdrop of as yet undetermined outcomes of the multilateral GATT negotiations. The United States had originally proposed a comprehensive "zero option" in GATT calling for the elimination of essentially all trade-distorting border measures and domestic support payments by its members. The zero-option proposal had proved untenable by the midterm GATT review in 1988. By the beginning of the NAFTA negotiations, the GATT discussions were focused on more restricted provisions for capping domestic support levels, partial reduction of export subsidies, and tariffication of import quotas, licenses, and other nontariff restrictions on trade. The nontariff restrictions were to be replaced by minimal market access provided by TRQs and high initial over-quota tariff levels, as in the case of U.S. sugar imports, with the over-quota tariffs subject to only modest reductions over time.

Faced with all this uncertainty about likely outcomes, the various agricul- 
tural interest groups took active roles in seeking to shape the NAFTA negotiations. They became aligned along two broad positions: those favoring their inclusion under provisions for agricultural trade liberalization and those favoring limits on the scope of the agreement with retention of some of the traditional trade restrictions. The basic positions of a selected subset of the most active agricultural and agriprocessing industry groups are shown in table 7.5.

\subsubsection{Proponents of Liberalization}

The American Farm Bureau Federation (AFBF) is the largest of the generalmembership organizations and is oriented toward competitive markets. At the outset of the NAFTA negotiations, the AFBF commissioned a study of the potential impacts on domestic agriculture of reduced trade barriers with Mexico. This study showed generally positive effects and provided the basis for the AFBF's approach to the negotiations. Although the study was criticized by some farm groups for minimizing the potential impacts on sectors that might face increased import competition, the AFBF concluded it would support comprehensive liberalization that included even the most politically sensitive import-competing commodities. The AFBF sought an active role in the negotiations, based partly on a view that it had not been vocal enough during negotiations for the Canada-U.S. FTA.

Table 7.5 Selected Agricultural Interest Groups

Favoring Liberalization

Favoring Limits to the Agreement

American Farm Bureau Federation (AFBF)

National Grange

National Farmers' Union (NFU)

American Soybean Association

National Corn Growers Association (NCGA)

U.S. Feed Grains Council

National Cattlemen's Association (NCA)

National Pork Producers Council

National Milk Producers Federation (NMPF)

Agribusiness Council, Inc.

Sweetener Users Association (SUA)

Food Marketing Institute

American Corn Growers Association (ACGA)

National Association of Wheat Growers

(NAWG)

National Peanut Council of America

Southwest Peanut Growers

Florida Sugar Cane League

U.S. Beet Sugar Association

Florida Citrus Mutual

Florida Fruit and Vegetable Association

Western Growers

United Food and Commercial Workers, AFL-

$\mathrm{ClO}$

Note: Representatives of the 22 groups listed were interviewed about their NAFTA position and activities during August-October 1993. The classification shown is based on the author's judgments from the content of the interviews and does not necessarily represent the legal or otherwise official positions of the groups. Interviewees were selected from a sample of 37 farm groups and 15 processing industry groups with representatives in the Washington, D.C., area. In addition, representatives of Florida Citrus Mutual and the Florida Fruit and Vegetable Association were interviewed at their state offices. The initial sample of groups was identified from the membership of USTR's Agricultural Policy Advisory Committee and 10 agricultural technical advisory committees and from respondents to a survey about NAFTA sent to 300 groups and individuals by the Senate Committee on Agriculture, Nutrition and Forestry. 
Many of the grain and oilseed commodity associations joined the AFBF in support for eliminating trade barriers under NAFTA. For these commodities, the 1987-90 export trend was interpreted to imply that reduced protection and increased income growth in Mexico would provide market opportunities. In particular, increased exports of U.S. corn and other feed grains were expected if Mexico further reduced its traditional support programs and trade restrictions. The National Corn Growers Association (NCGA), the largest organization of corn producers and processors (with about 25,000 members), became an active supporter of NAFTA. The NCGA sought maximum opening of the Mexican market. It requested an initial TRQ for corn of 3.5 MMT, which was considered a level "tough for Mexico to grant." The NCGA expected further gains in derived demand for corn from a growing Mexican market for U.S. livestock products.

Livestock producers concurred in anticipating gains from liberalized trade with Mexico. The approach toward the negotiations of the National Cattlemen's Association (NCA) was representative of their efforts. The NCA was interested in expanding foreign market access and cited as a successful precedent the 1988 bilateral agreement to replace Japanese beef quotas with TRQs and declining over-quota tariff levels. Mexico did not have import quotas on beef when the NAFTA negotiations were initiated, but there was uncertainty about continued openness of the border and the levels at which tariffs on livestock products would be set.

The corn growers and cattlemen, among others, were actively engaged in the NAFTA negotiations. The NCGA had extensive discussions of goals and strategy in meetings of their voting delegates, stayed in close contact with the senior negotiators, and kept their supporters in Congress informed about the process. The NCGA was represented on the Grains and Feed Technical Advisory Committee of the United States trade representative (USTR), one of 10 agricultural technical advisory committees (ATACs) established as part of USTR's private sector advisory structure by the Trade Act of $1974 .{ }^{3}$ The NCA worked closely with the broader Meat Industry Trade Policy Council and was represented on USTR's Livestock and Livestock Products Technical Advisory Committee, its multicommodity Agricultural Policy Advisory Committee, and its president's Advisory Committee on Trade Policy and Negotiations (ACTPN). Representatives of the NCA concluded that they had ample opportunities to influence the outcome of the negotiations through regular interaction with USDA and USTR and through Congress.

3. The presidentially appointed private sector advisory system is arranged in three tiers: the president's Advisory Committee on Trade Policy and Negotiations; seven policy advisory committees (Services, Investment, and Intergovernmental, managed solely by USTR, and Industry, Agriculture, Labor, and Defense, managed jointly with other agencies); and more than 30 technical, sectoral, and functional advisory committees. The 10 agricultural technical advisory committees (ATACs) address cotton, dairy products, fruits and vegetables, grains and feed, livestock and livestock products, oilseed and products, poultry and eggs, processed foods, sweeteners, and tobacco. 
Support for an agreement to liberalize agricultural trade also came from representatives of many processing and supply industries. Typical of the industry organizations was the Sweetener Users Association (SUA), sponsored by 16 major food processors. While recognizing that the sweetener users had little influence on the agricultural committees of Congress, an SUA representative and two other user-industry representatives served on USTR's Sweeteners Technical Advisory Committee. Other processing industries were represented on commodity-specific technical advisory committees (oilseeds, dairy, and cotton) and on the separate Processed Foods Technical Advisory Committee.

Representatives of the dairy industry were also marginally among the supporters of eliminating trade barriers with Mexico and Canada. Although protected by import quotas, the dairy industry had initiated a broad lobbying effort to obtain legislative authority for industry-funded export subsidies-called their "self-help" legislation. Industry statements suggested this was viewed as a means to reduce domestic supply and obtain higher domestic prices by exploiting an inelastic domestic demand (Barr 1993). Since Mexico produced few import-competing dairy products and accounted for a large fraction of U.S. dairy exports, as shown in table 7.1, greater market access under NAFTA was consistent with the industry's overall initiative. The industry also believed that it could be competitive in Canada if dairy trade restrictions were eliminated.

Throughout the NAFTA negotiations, a coalition of dairy cooperatives, represented by the National Milk Producers Federation (NMPF), remained noncommittal but not opposed to NAFTA. While supporting expanded export opportunities, the NMPF argued against tariffication of U.S. section 22 dairy quotas, especially if Canada maintained its import barriers. The NMPF was represented on the Dairy Technical Advisory Committee and worked closely with USDA and USTR at the staff and policy levels to develop strong rules of origin in the event U.S. quotas for Mexico were eliminated on a bilateral basis. Representatives of NMPF also "wrote the obligatory letters" and participated in congressional hearings. Otherwise, they spent "almost no time on the Hill" because they felt the congressional agricultural committees were less interested in dairy issues than issues concerning peanuts and sugar.

\subsubsection{Proponents of Limits on the Agreement}

Among the groups that were opposed to the NAFTA negotiations or sought limits on the scope of any agreement, the National Farmers Union (NFU), a general organization with membership concentrated in the upper midwestern states, and several other small general-membership organizations had long argued for policies to raise prices for farm products through restrictive supply management. Because of NFU's support of supply management rather than export-based market expansion, its representatives viewed themselves as "not being allowed at the table" and, likewise, as not having been interested in negotiating details of a trade agreement. The NFU, which claims to represent the 
traditional family farmer against agribusiness interests, sought intensive congressional involvement, arguing that the Congress would "give the left out entities a chance to have their say."

The NFU view of the negotiations was shared by the American Corn Growers Association (ACGA). The ACGA, with 10,000 members, also seeks higher domestic corn prices through restrictive supply management. It traced its origins to a split with the NCGA over endorsing lower corn loan rates in 1985 as a means to increase international competitiveness. ${ }^{4}$ The ACGA opposed NAFTA and was not interested in participating in the negotiations for specific provisions.

Wheat producers also took a contentious approach toward NAFTA. They raised concerns that U.S. competitiveness was being adversely affected by nontransparency of the pricing policies of the Canadian Wheat Board-the exclusive agent for Canadian wheat exports - and by eastbound grain transportation subsidies in Canada. These were among the issues left unresolved under the Canada-U.S. FTA. The U.S. producers argued that increased Canadian exports of wheat into the United States and Mexico after 1988 (capturing of a large share of the Mexican wheat market) were the result of Canadian export subsidies. The Canadian producers counterargued that their export shipments resulted from the price differentials and U.S. shipment patterns resulting from the United States' own wheat export enhancement (subsidy) program.

To address their concerns, the National Association of Wheat Growers (NAWG) sought elimination of Canadian subsidies and imposition of import restrictions (wheat had been subject to section 22 quotas that were allowed to lapse in 1974 when world wheat prices and U.S. exports rose sharply). The wheat producers, unlike the NFU and ACGA, actively engaged in the NAFTA negotiating process to press their case. The NAWG kept its members "highly informed" of its objectives, participated in hearings of the agricultural committees of Congress, worked through contacts at USDA and USTR, and brought what its representatives termed "collaborative input from Congress" to bear on the negotiators. A NAWG representative served on USTR's Grains and Feed Technical Advisory Committee but viewed the committee as having little influence.

Limits on the access to U.S. markets provided by NAFTA were also sought by representatives of the cane and beet sugar industries and the commodities protected by import quotas. These sectors shared two concerns at the outset of the negotiations: that elimination of the trade restrictions with Mexico would create potential competition from Mexican producers, and that it would set a precedent for further weakening of protective quota restrictions either in subse-

4. With the high value of the U.S. dollar in the mid-1980s, world corn prices were resting on the U.S. loan rate and U.S. exports had declined markedly. Lowering the loan rate under these circumstances lowered domestic market prices, to which the ACGA objected, but also reduced the quantities going into storage and increased exports. 
quent negotiations or by subjecting the remaining restrictions to legal challenge (Gillon 1992).

With their mutual concerns, a strong coalition might be expected to have developed among the protected sectors. However, the views of the dairy industry were tempered by its recognition of the limited competition and potential export opportunities that NAFTA might create, as described above. Cotton producers and processors, represented by the National Cotton Council of America (NCCA), also tempered their position. They recognized that expanded export opportunities might arise if a North American free trade area for textiles and apparel was associated with strong rules of origin for the fiber content of the final products - industry perceptions that mirrored the argument made against the trade diversionary effects of such rules of origin by Krueger (1993).

The moderated views of the dairy and cotton producers (assuming there were strong rules of origin) left producers of peanuts and sugar as the most strident proponents of limits on NAFTA's market access provisions. Although Mexico was a net peanut importer, the U.S. producers expressed intense opposition to possible import competition, partly on the basis of ostensible concern about illegal transshipments through Mexico of non-NAFTA peanuts from the Caribbean and elsewhere if quotas were removed on a bilateral basis. The peanut producers, represented primarily by nine state organizations, pressed their case through USTR's Oilseed and Products Technical Advisory Committee and through Congress. The producers argued that their concerns were exacerbated because consideration of NAFTA came after several years of what they termed "extreme uncertainty" about the effects a GATT agreement could have on the peanut support program by increasing foreign access to their domestic market.

The sugar sector's similar view of liberalized trade under NAFTA as a threat to their interests came in response to an initial Mexican request for access to the U.S. market of a sugar TRQ of 1.5 MMT - more than the combined TRQs of all other countries. The U.S. producers claimed they had been assured by the Bush administration that the traditional pattern of trade-with Mexico a net importer of sugar-would not be disrupted by NAFTA. In this context, they viewed the Mexican access request as a "shot out of the barrel." This volume of exports was considered possible if Mexican production and refining were modernized and if a shift in relative prices between corn and sugar resulted in the use of corn sweeteners in the Mexican soft drink industry.

The sugar producers took a strong stand in defense of their protected domestic market during the NAFTA negotiations. They opposed any trade liberalization that would put pressure on the U.S. sugar support program. Illustrative of their potent avenues of influence was the appointment to USTR's Agricultural Policy Advisory Committee of the executive vice-president of the Florida Sugar Cane League, representing one of the major sugar-producing states. This appointment came after intensive pressure on the Bush administration by members of Congress. 
Representatives of some commodities in the horticultural sector also expressed strong reservations about trade liberalization with Mexico. The USTR's Fruits and Vegetables Technical Advisory Committee became a forum for discussing the positions of the diverse interest groups within this sector. An early statement in September 1990 cited concerns about increased import competition and called for adequate transition periods for tariff reductions (Fruits and Vegetables Agricultural Technical Advisory Committee 1990). It noted that price-based tariff snapbacks to protect Canadian farmers against import surges that depressed domestic prices had been included in the Canada-U.S. FTA and called for similar provisions in NAFTA to protect U.S. farmers. Florida vegetable producers also sought exemptions from the agreement until disparities in environmental and labor conditions were eliminated, a stance not supported by the producers and processors in California.

Florida citrus producers, represented on USTR's Processed Foods Technical Advisory Committee, were one of the most active groups to oppose NAFTA, arguing they would be "one of the losers" from an agreement with Mexico. The Florida citrus producers initially proposed that orange juice be excluded from the agreement for 20 years. Their proposal would have maintained existing protection for the productive life of the extensive new plantings that took place in southern Florida after severe freezes in the 1980s.

With the import-competing Florida producers of citrus and other winter fruits and vegetables joining the sugar sector in opposition to NAFTA, a strong coalition emerged to press the ce e of Florida agriculture. These interests developed a unified position with other agricultural groups. The Florida Farm Bureau and the Florida Cattlemen's Association joined the coalition, and both eventually broke ranks with their national organizations' support for NAFTA. The state commissioner of agriculture became an active proponent of the Florida concerns, and the producers received endorsements from the state legislature and elsewhere. Together, the agricultural groups exerted a powerful influence on Florida's large congressional delegation, whose cooperation they judged to be "superb."

\subsubsection{Measuring the Activity Levels}

Both proponents of liberalization of agricultural trade and proponents of limits on the scope of the agreement were actively engaged in asserting their positions during the NAFTA negotiations. Avenues for influence ranged from individual contacts with USDA and USTR at the staff and policy levels, to participation in USTR's 10 ATACs and its Agricultural Policy Advisory Committee, to intervention by members of the agricultural committees of Congress or other individual members, to direct interactions with the president. Specific groups were often engaged in the process through a variety of channels, but a reasonable generalization is that groups that found the broad outline of the negotiations amenable to their interests were able to work closely with the 
negotiators and their technical staffs, while groups opposed to the general direction of the negotiations sought redress through Congress.

One quantitative indicator of the levels of interest in NAFTA among the various agricultural sectors comes from the information about the agreement provided by publications aimed at their different constituents. A summary of articles about NAFTA in 30 general and commodity-specific agricultural magazines is presented in table 7.6. The sample period covers the original negotiations, the change in administration after the 1992 elections, and the initial discussions of the side-agreements negotiated by the Clinton administration.

Using the average number of articles about NAFTA per issue of a magazine as a measure of intensity of attention, the highest average was found for the magazines in the sugar sector (1.08), followed by grains and oilseeds $(0.80)$, and horticulture (0.48). General farm magazines and the magazines in the dairy and peanut sectors show somewhat lower averages $(<0.30)$, and the lowest average $(0.11)$ was found for livestock and poultry publications.

Based on a qualitative content assessment, the articles were also classified

Table 7.6

Coverage of NAFTA during the Negotiations: Selected Sample of Farm Magazines

\begin{tabular}{|c|c|c|c|c|c|c|c|c|}
\hline \multirow[b]{3}{*}{ Category } & \multicolumn{4}{|c|}{ Number of: } & \multicolumn{4}{|c|}{ Type of Article } \\
\hline & \multirow[b]{2}{*}{ Magazines } & \multirow[b]{2}{*}{ Issues } & \multirow{2}{*}{$\begin{array}{l}\text { Articles } \\
\text { on } \\
\text { NAFTA }\end{array}$} & \multirow{2}{*}{$\begin{array}{c}\text { Articles } \\
\text { per } \\
\text { Issue }\end{array}$} & \multirow[b]{2}{*}{ News } & \multicolumn{3}{|c|}{ Analysis or Opinion } \\
\hline & & & & & & Factual & Supportive & Opposed \\
\hline General & 7 & 193 & 52 & 0.27 & 16 & 19 & 10 & 7 \\
\hline $\begin{array}{c}\text { Grains and } \\
\text { oilseeds }\end{array}$ & 3 & 108 & 87 & 0.80 & 38 & 12 & 27 & 10 \\
\hline $\begin{array}{l}\text { Livestock } \\
\text { and } \\
\text { poultry }\end{array}$ & 6 & 184 & 21 & 0.11 & 4 & 2 & 14 & 1 \\
\hline Dairy & 2 & 49 & 14 & 0.28 & 8 & 3 & 3 & 0 \\
\hline Peanuts & 3 & 56 & 15 & 0.27 & 7 & 3 & 0 & 5 \\
\hline Sugar & 2 & 26 & 28 & 1.08 & 9 & 6 & 1 & 12 \\
\hline Horticulture & 7 & 185 & 88 & 0.48 & 21 & 16 & 26 & 25 \\
\hline Total & 30 & 801 & 305 & & 103 & 61 & 81 & 60 \\
\hline
\end{tabular}

Note: Selection was based on a search at the National Agricultural Library and the Carroll $\mathbf{M}$. Newman Library at Virginia Polytechnic Institute and State University. The subset of magazines included in the review are (1) general: Farm Journal, Kiplinger's Agricultural Letters, Ohio Farmer, Progressive Farmer, Southeast Farm Press, Successful Farmer, Top Producer; (2) grains and oilseeds: Feedstuffs, Soybean Digest, Wheat Grower; (3) livestock and poultry: Drover's Journal, Inside Beef Today, Meat and Poultry, Pigs Monthly, Sheep Breeder Highlights, World Poultry; (4) dairy: Dairymen's Digest, Hoard's Dairymen; (5) peanuts: Peanut Farmer, Peanut Grower, Virginia-Carolina Peanut News; (6) sugar: Cane Press, Sugar Beet Grower; (7) horticulture: American Fruit Grower, American Vegetable Grower, California Grower, California Tomato Grower, Citrus and Vegetable Magazine, Spudletter, Virginia Fruit. The sample period is generally August 1990 to May 1993, but in 11 cases a somewhat shorter sample was dictated by availability. 
as being either reports of news or presentations of analysis or opinion. The latter articles were divided among those that presented factual material without either explicit support or opposition to the agreement, those that were supportive of the agreement, and those in which opposition was expressed. Magazines in the sugar sector not only showed the highest intensity level but the articles were primarily expressions of opposition. Articles in the grains and oilseeds and horticulture magazines were split more evenly among news reports, analysis, and differing opinions. Largely factual coverage of NAFTA was presented in the general farm magazines, while articles in the small sample of dairy and peanut magazines were evenly divided between news and analysis or opinion, with a generally supportive position in the dairy magazines and opposition in the peanut magazines.

A second quantitative measure of the involvement of the various interest groups in the NAFTA negotiations is provided by their testimony before congressional committees. There were 13 hearings at which agricultural groups were represented during the negotiations for the initial-agreement and the subsequent side-agreements (three each by committees or subcommittees on agriculture, energy, and commerce, and ways and means, and one each by foreign affairs, public works, small business, and education and labor).

Testimony at the various hearings reflected the diverse views of the generalmembership and commodity-specific agricultural groups. Of 20 appearances by general-membership organizations, the AFBF and NFU were represented three times each, with remaining testimonies from a variety of other groups. Supporters of trade liberalization from the grains and oilseeds sector testified 12 times, the NAWG had three opportunities to raise its concerns about Canadian policies, and the ACGA testified once against the agreement. Livestock and poultry producers testified four times in support of the agreement. Dairy and cotton groups were also represented four times each, and peanut interests testified two times. Sugar producers testified eight times, while the industrial sweetener users testified only once. The horticultural sector was represented in 44 testimonies. The Florida coalition was represented six times by vegetable groups, four times by the state commissioner of agriculture, and twice by the citrus association. California and other western and Mexican horticultural groups were represented 26 times in the hearings.

A third basis for assessing the levels of activity among the various agricultural interest groups comes from informal observations of the negotiators and commodity group representatives. One key negotiator indicated that despite the efforts of the AFBF and other supporters, there was not a forceful lobby for comprehensive trade liberalization during the negotiations. Negotiators on both sides frequently cited keeping defensive domestic interests "on board" as their most difficult task, and many participants in the process acknowledged that established interests that feared losses were better organized than the potential beneficiaries of greater international trade. As one observer put it, "there was no white corn growers association ready to claim the benefits of expanded 
export opportunities into Mexico," or, as several participants noted, nothing motivated a commodity group like "getting its ox gored."

\subsection{Agricultural Provisions of NAFTA}

Against the backdrop of the various producer interests, high-level negotiators for Mexico and the United States agreed in February 1992 that all agricultural products would be included in the long-run provisions for trade liberalization. The U.S. agricultural groups may have exerted some influence on this decision, but informally the U.S. negotiators attributed it largely to the willingness of Mexico to include its politically sensitive corn sector, leaving little room for other exclusions. Canada continued to object to full coverage of the agricultural provisions, and the U.S. farm groups and others favoring liberalized trade were unable to exert sufficient influence for their negotiators to extract Canadian concessions. Instead, the negotiators agreed that pending modification by a GATT agreement, the Canada-U.S. FTA was to remain in effect for bilateral Canada-U.S. agricultural trade and a similar bilateral agreement on agricultural tariffs and market access would be developed between Mexico and Canada.

Agreements on the provisions of NAFTA were announced by the negotiating parties in August 1992. For Mexico and the United States, the agricultural tariff and market access provisions called for all quotas and licenses to be converted to TRQs upon enactment. For imports above the TRQs, over-quota tariffs were set to provide initial protection equivalent to the previous nontariff measures. The over-quota tariffs were to be completely phased out over adjustment periods of 10 or, in some cases, 15 years. Almost 21 percent of the value of pre-NAFTA trade received this type of adjustment mechanism. An additional 23 percent of the value of pre-NAFTA trade was subject to straightforward phasing out of tariffs over 5 to 15 years, while about 56 percent of the value of bilateral trade occurring under the pre-NAFTA restrictions already was, or was scheduled under NAFTA to immediately become, duty free.

In addition to its market access and tariff provisions, NAFTA addressed issues concerning grades and standards and sanitary and phytosanitary regulations related to human, animal, and plant health. Trade restrictions arising in these areas had traditionally been problematic, and the agreement enunciated principles intended to reduce these sources of friction. The principles included that grades and standards be applied on a nondiscriminatory basis. Each country also retained the right to maintain its own health and safety standards as long as they were "scientifically based and administered in a forthright and expeditious manner." Detailed dispute settlement procedures were established in an effort to provide a forum for resolution of conflicts among the parties.

While placing no restrictions on domestic support levels, the long-run NAFTA provisions for agriculture accomplished on a bilateral basis the basic objective with respect to trade barriers of the initial U.S. zero-option GATT 
proposal. This was a notable achievement in comparison to previous bilateral efforts to liberalize trade of agricultural products, which had not addressed quantitative restrictions, or the then-pending Uruguay Round GATT negotiations, in which tariffication of quotas and licenses was being considered with only minimal requirements for market access and reduction of the levels of over-quota tariffs over time. The NAFTA result led Hufbauer and Schott (1993) to conclude, for example, that there was "laudable progress in the liberalization of farm trade barriers." In their widely cited evaluation, they assigned an "A" grade to the outcomes of the negotiations for agriculture, one of the four highest grades assigned among 18 aspects of the agreement. Similarly, a key U.S. agricultural negotiator expressed the exuberant view that NAFTA would create "the freest trade in agricultural products between any two countries." Other anecdotal evidence also supports a sense of accomplishment among the negotiators.

One cannot be as sanguine about the short-run NAFTA provisions for agriculture. For the commodities protected by import quotas or licenses, market access under the initial TRQs was based on 1989-9l trade levels. Quantities receiving market access under the TRQs were scheduled to increase at only a 3 percent annual compound rate. Over-quota tariffs provided high levels of protection against additional imports in the short and medium run. Proposed initial Mexican over-quota tariffs were 215 percent for corn and 260 percent for chicken, for example, while proposed U.S. over-quota tariffs were 70 percent for cheeses and 123 percent for shelled peanuts. Corn, dry edible beans, milk powder, and peanuts were considered particularly sensitive commodities and received 15-year adjustment periods for phase-out of the over-quota tariffs.

More complex protective TRQ transition mechanisms were negotiated for sugar. Mexico agreed to raise its external sugar tariff to the U.S. over-quota level by the seventh year of the agreement. Mexican access to the U.S. sugar market was restricted by a TRQ of 25,000 metric tons during this period, with the over-quota tariff between Mexico and the United States phased out over 15 years. Mexico gained increased low-duty access to the U.S. market after seven years if it became a surplus sugar region based on domestic production and consumption, with unlimited access for its surpluses if it became a surplus producer for two consecutive years. The negotiators did not address the question of whether the United States would maintain its aggregate global TRQ for sugar, in which case any Mexican surpluses would divert trade from other foreign suppliers, or whether U.S. commitments to other countries would be honored, in which case the Mexican surpluses would put downward pressure on U.S. production and prices.

A complex TRQ was also negotiated for frozen concentrated orange juice, which had been subject previously only to tariff barriers. The within-quota imports were assessed a tariff of one-half the most-favored-nation (MFN) level. The over-quota tariffs were set initially at MFN rates, then declined lin- 
early by 15 percent during the first six years, remained constant for four years, and were phased out over an additional five years.

Two additional adjustment mechanisms were included in the negotiated agreement to address other concerns of the U.S. producers of horticultural products. First, tariffs on cucumbers, asparagus, broccoli, melons, dried onions, and garlic were phased out over 15 years instead of 10 years. Second, a mechanism named a special safeguard was applied to seasonal U.S. imports of tomatoes, peppers, onions, eggplants, squash, and watermelons. The special safeguard commodities were to have TRQs with 10-year periods of adjustment, but the over-quota tariffs were held at MFN levels during the adjustment period, then eliminated in one step at the end.

A final adjustment mechanism was provided by the emergency action provisions of the agreement. During the transition periods, a tariff reduction could be suspended and the MFN tariff rate reestablished for up to four years if imports were found to have become, or to threaten to become, a substantial cause of serious injury to a domestic industry. The investigating authority for emergency action decisions for the United States was the International Trade Commission (ITC). Emergency actions were limited to a single application for any commodity during the transition period. After the transition period had expired, such actions could only be applied with the consent of, and compensation to, the other party.

From these brief descriptions of the transition mechanisms for agricultural trade, the influence of various producer groups on the negotiations is evident. Within the framework of long-run liberalization of trade with Mexico, likely gainers among U.S. producers confronted the lengthy adjustment mechanisms included to protect Mexican farmers. Import-competing U.S. commodities were provided with similar adjustment protection. Given these provisions, the end-constraint of complete tariff elimination is crucial to the assertion that NAFTA accomplished long-run bilateral trade liberalization for agriculture.

\subsection{Estimated Effects of the Agricultural Provisions}

Several quantitative estimates have been made of the long-run effects of NAFTA on Mexico-U.S. agricultural trade. The range of these estimates is illustrated in table 7.7. The results from a model developed by Grennes and Krissoff (1993) with support from USDA are compared to composite assessments underlying the preliminary (September 1992) and revised (March 1993) reports from the secretary of agriculture's Office of Economics. The latter assessments were frequently used by the Bush and Clinton administrations in congressional testimony and elsewhere.

Grennes and Krissoff developed a 29-commodity, three-region (Mexico, United States, and rest of world) partial equilibrium model using the Armington assumption that commodities from different regions are close but im- 
Table 7.7

Estimates of NAFTA's Long-Run Effects on Mexico-U.S. Agricultural Trade (million dollars)

\begin{tabular}{|c|c|c|c|c|}
\hline \multirow[b]{2}{*}{ Commodity } & \multicolumn{2}{|c|}{$\begin{array}{c}\text { Static Model } \\
\text { (Grennes-Krissoff) }\end{array}$} & \multicolumn{2}{|c|}{$\begin{array}{c}\text { Composite Estimates } \\
\text { (USDA) }\end{array}$} \\
\hline & $\begin{array}{l}\text { U.S. } \\
\text { Imports }\end{array}$ & $\begin{array}{l}\text { U.S. } \\
\text { Exports }\end{array}$ & $\begin{array}{l}\text { U.S. } \\
\text { Imports }\end{array}$ & $\begin{array}{l}\text { U.S. } \\
\text { Exports }\end{array}$ \\
\hline Grains and oilseeds & 2 & 430 & 0 & - \\
\hline Corn & 0 & 219 & 0 & 280 \\
\hline Other coarse grains & 0 & 123 & 0 & - \\
\hline Wheat & 0 & 2 & 0 & 40 \\
\hline Soybeans (includes meal and oil) & 0 & 34 & 0 & 220 \\
\hline \multicolumn{5}{|l|}{ Other oilseeds (includes meal and } \\
\hline oil) & 2 & 48 & 0 & - \\
\hline Livestock and poultry & 56 & 48 & 293 & 1,508 \\
\hline Cattle & 56 & 18 & 266 & 879 \\
\hline Beef & 0 & 6 & 2 & 139 \\
\hline Pork & 0 & 9 & - & 440 \\
\hline Poultry & 0 & 15 & - & 50 \\
\hline Section 22 commodities & - & - & - & - \\
\hline Dairy & 0 & 2 & - & 138 \\
\hline Cotton & 0 & 1 & - & - \\
\hline Peanuts & - & - & - & 1 \\
\hline Sugar & 0 & 0 & - & - \\
\hline Horticultural & 0 & 0 & 198 & - \\
\hline Orange juice (frozen concentrate) & 45 & 0 & 22 & - \\
\hline Fruits and vegetables & 58 & 0 & 176 & 163 \\
\hline Melons & 11 & 0 & 28 & - \\
\hline Cucumbers & 9 & 0 & 9 & - \\
\hline Onions & 7 & 0 & 18 & - \\
\hline Peppers & 5 & 0 & 13 & - \\
\hline Tomatoes & 26 & 0 & 17 & - \\
\hline Other & - & - & 91 & - \\
\hline Other Products & 3 & 3 & 202 & 273 \\
\hline Total & 164 & 485 & 693 & 2,623 \\
\hline
\end{tabular}

Sources: Grennes and Krissoff (1993); USDA (1993); private communication with the authors and USDA's Office of Economics.

Note: (-) Not available.

perfect substitutes. An equilibrium solution estimated under the assumption that agricultural trade barriers between Mexico and the United States were eliminated was compared to the equilibrium solution obtained incorporating price differentials equivalent to the tariffs and nontariff barriers in 1988. Thus, Grennes and Krissoff estimated the long-run impact of NAFTA on annual trade flows with technology and national incomes implicitly held constant.

Consistent with the basic comparative advantages reflected in the preNAFTA trade flows, the Grennes-Krissoff model showed an increase in U.S. 
grain, oilseed, and livestock exports to Mexico under NAFTA, while Mexico increased its exports of horticultural products and live cattle. Agricultural exports from the United States to Mexico increased by $\$ 485$ million annually and agricultural imports from Mexico by $\$ 164$ million. Grennes and Krissoff pointed out that appreciation of the U.S. dollar relative to the Mexican peso could reverse the estimated net trade effects, and Grennes (1993) noted that the discounted value of the gains from trade were reduced substantially by the long transition periods involved.

In terms of adjustments within each country, the production and price of corn in Mexico were estimated to decline by 7.3 and 15.9 percent, respectively, in the Grennes-Krissoff model, with proportional impacts on other coarse grains. The impacts on U.S. grain and oilseed production and prices were positive but negligible. Effects on the livestock sector were also relatively larger in Mexico than in the United States. Grennes and Krissoff did not model a shift from sugar to corn sweeteners in the Mexican soft drink industry; thus, they found essentially no change in Mexico-U.S. sugar trade. For the horticultural products included in their model, Mexican production expanded while U.S. production and prices fell. No horticultural product experienced a production or price decrease of more than 2 percent.

The results from the Grennes-Krissoff model suggest moderate overall benefits of NAFTA for U.S. agricultural producers. The reports by USDA's Office of Economics asserted a more positive view of NAFTA's potential beneficial impacts. The analysis for these reports was based on a variety of USDA model outcomes and analysts' judgments. It also incorporated estimated demand effects resulting from a projected increase in annual economic growth in Mexico of 0.5 percent of GDP due to NAFTA.

The final Office of Economics report concluded that U.S. agricultural exports to Mexico were likely to be more than $\$ 2.5$ billion higher annually with NAFTA by the end of the 15-year adjustment period-an increase five times the level estimated by Grennes and Krissoff-while imports of agricultural products from Mexico would increase by $\$ 500$ to $\$ 600$ million. The difference between the export estimates by the Office of Economics and Grennes-Krissoff is attributable mostly to greater exports of income-responsive livestock and poultry ( $\$ 1,508$ million compared to $\$ 48$ million), with somewhat greater exports of grains and oilseeds, dairy products, and fruits and vegetables. The Office of Economics estimated greater U.S. imports of cattle, horticultural commodities, and other products.

Among the commodities protected by U.S. import quotas, the Office of Economics concluded that exports of milk powder to Mexico were expected "to grow by about 20,000 metric tons by the end of the 15-year transition period," while Mexican exports of dairy products to the United States were unlikely to increase. The Office of Economics concluded that U.S. exports of both raw cotton and the cotton equivalent of textiles and apparel would increase under 
NAFTA, and that the United States would "enhance its role as a major supplier of peanuts to Mexico," with" "little reason to expect Mexico to become a significant supplier of peanuts."

The reports by the Office of Economics also downplayed the possibility of adverse impacts of NAFTA on domestic producers of sugar and winter fruits and vegetables. Specific estimates of the value of increased imports were not published, but the final report concluded for sugar that it was "uncertain to what extent Mexico might achieve a net production surplus" and that "any net production surplus would likely develop gradually because of . . . the constraints to switching to corn sweeteners in the Mexican soft drink industry." For winter fruits and vegetables, the Office of Economics concluded that any price effects would be moderated by the 10- and 15-year adjustment periods and the special safeguards. The potential increased competition for citrus was acknowledged with the qualifier that the effects on the U.S. industry were "expected to be small" (U.S. imports "about 3-4 percent higher with NAFTA" and U.S. prices "slightly lower").

\subsection{Interest Group Assessments of the Agreement}

The USTR's Agricultural Policy Advisory Committee (1992) and 10 ATACs (1992) completed their legislatively mandated assessments of NAFTA in September 1992. The Agricultural Policy Advisory Committee generally reflected the position of the AFBF, concluding that it "believes that the proposed NAFTA provides long-term net export growth opportunities for U.S. agriculture and is in the economic interest of the United States."

The commodity groups that had supported bilateral trade liberalization under the agreement were also mostly satisfied with the results of the negotiations. In their ATAC report, the feed grain representatives stated that their market access objectives "had been met." The oilseed producers and processors noted that the agreement "will afford the U.S. industry with a comparative advantage in the Mexican market over imports from competing suppliers in South America, Europe and elsewhere." Livestock (and poultry and egg) producers concluded that the negotiations were generally successful but called attention to the "glaring differences in state and national veterinary service infrastructure." They noted the need for "animal health programs to be in place in Mexico that will protect the livestock industries of both countries." Subsequently, the livestock producers expressed renewed concerns when Mexico imposed new tariffs of 15 to 25 percent on livestock and meat products in November 1992. The NCA saw NAFTA as an opportunity to remove these tariffs and the threat of future tariffs.

Support for the negotiated agricultural provisions of NAFTA was also expressed by many food-processing industries. Representatives of the industrial sweetener users expressed appreciation for "the manner in which the trade negotiators have endeavored to keep us informed of the details of these com- 
plex negotiations" and strongly supported the agreement. The Processed Foods Technical Advisory Committee (except citrus) also supported the agreement but pointed out that its acceptance of tariffication of section 22 quotas under NAFTA was "based solely on the status of production/consumption considerations in the three countries." Similarly, the Dairy Technical Advisory Committee, while noting that the dairy sector opposed tariffication of section 22 quotas, concluded that the TRQs and rules-of-origin provisions were "sufficient to prevent disruptive levels of dairy imports" and that U.S. dairy producers would benefit if they were able to take advantage of the export opportunities NAFTA created.

In contrast to these expressions of support for NAFTA (even with technical reservations), many of the agricultural groups that had sought limits on the agreement were not satisfied with the negotiated outcomes. The NFU continued to express broad opposition to the agreement, and wheat producers expressed dissatisfaction that their concerns about Canadian Wheat Board pricing and grain transportation subsidies were not addressed. The NAWG acknowledged that there had been a lot of access to the negotiating process but concluded that "whether you get what you want is another question." Their ATAC representative viewed the Republican administration as unresponsive. Foreshadowing the bargaining that would occur during the congressional debate to follow, he recommended that the "important matters (concerning Canada) be addressed in the implementing legislation."

The import-quota-protected sectors other than dairy also continued to express opposition to NAFTA. Cotton producers noted their opposition to elimination of section 22 quotas and argued that there were "no reliable estimates of how traditional cropping patterns will be affected by provisions of the NAFTA." Cotton processors, in contrast, endorsed the agreement but not "expansion of NAFTA to include other countries."

Peanut producers and shellers remained more unified in their opposition to the agreement. They called attention to Canada's exclusion of "sensitive products" and concluded that "the U.S. government should have insisted on the same provisions for U.S. Section 22 commodities." The Washington representative of many of the state peanut organizations faulted the U.S. negotiators for not attaining this outcome but gave credit to Congressman de la Garza, chairman of the House Committee on Agriculture, for "taking care" of peanut concerns for tough rules of origin "as late as the last day of the negotiations."

Sugar producers also remained unified in their opposition to the outcome of the NAFTA negotiations. They accused the administration of being out to "get sugar" and objected that the negotiations proceeded "in great haste and unprecedented secrecy." Twisting the effects of high domestic sugar prices to their own ends, their representatives argued that the sugar sector had gone through a difficult rationalization to, as they put it, "modernize the domestic industry." They argued that it would be "unfair" for U.S. producers to bear the burden of adjustment if lower Mexican corn prices and higher sugar prices resulted in 
similar "modernization" in Mexico (use of high-fructose corn sweeteners in the soft drink industry) and consequent sugar surpluses and exports. The sugar producers asserted that they had "no hand" in the provisions that were included in the negotiated agreement and called for two fundamental modifications. First, they argued that the Mexican surplus status be calculated "not just on the basis of sugar, but on caloric sweeteners, including corn sweeteners." Second, they argued that Mexican access to the U.S. market "be capped at a growing TRQ" for the full 15-year adjustment period even if Mexico became a surplus producer for two consecutive years. Representatives of the producers on the sweeteners ATAC also raised concerns about whether NAFTA would be extended to other countries. Although not mentioned specifically, these countries potentially included Cuba with its annual sugar surpluses in excess of 5 MMT.

Finally, the horticultural sector, like the cotton industry, held mixed views about the negotiated agreement. Winter fruit and vegetable producers in Florida continued to oppose NAFTA. The Florida producers felt they had pursued all of the avenues open to participating in the negotiations and viewed their access to the negotiators as good throughout most of the process. In the end, however, like the sugar producers, they concluded that the Bush administration had "failed to honor its commitment to Congress to provide protection for the most sensitive products." The Florida producers suggested again that some winter fruits and vegetables be excluded from the agreement. At a minimum, they argued that the tariff phase-out periods be extended to 20 years for sensitive commodities, with more commodities included in the category subject to the longest transition.

Reactions of other horticultural producers illustrated the diversity of interests within this sector. California producers generally expressed less opposition to the agreement than producers in Florida. The U.S. wine industry, in particular, was dissatisfied with the phase-out periods for Mexican tariffs being too long. Together with potato producers, who had similar concerns, the wine industry concluded it could not support the agreement unless more favorable access to the Mexican market were obtained.

\subsubsection{Survey by the Senate Committee}

To complement USTR's advisory committee reports and other expressions of the views of producers and other interested parties, Senators Leahy and Lugar, chairman and ranking member of the Senate Committee on Agriculture, Nutrition and Forestry, conducted a survey of opinions about NAFTA. As had been done for previous important policy decisions, the survey was mailed to 300 groups and individuals identified by the committee staff as having an interest in the issues. By June 1993, 124 responses were received. The relatively low response rate may suggest that the survey was not considered an effective means to express an opinion to Congress by many interest groups. Nevertheless, the responses provide a broad overview of the positions of the various agricultural interests. 
Based on a qualitative analysis of the responses (e.g., stated position, strength of the language, number of caveats), 24 provided strong support for the agreement, 51 provided support, 21 were opposed, 9 were strongly opposed, and 19 took no position. ${ }^{5}$ Among the general-membership organizations, positions remained divided. Several government and public agencies submitted letters (with opposition from Florida and support from Arizona, California, and Texas), and the embassies of five Caribbean countries submitted an unsolicited letter of opposition because of potential reductions of their sugar TRQs. Grain and oilseed producers and some livestock groups were supportive of the agreement, but others had reservations or had not taken a position. The dairy and cotton respondents were divided between supporters and those not having a position, while peanut and sugar producers expressed their strong opposition. Respondents among horticultural interests again reflected diverse views, with opposition expressed by the coalition of Florida producers. Food processors and suppliers and the forestry industry overwhelmingly supported NAFTA, while the United Food and Commercial Workers, AFL-CIO, expressed organized labor's opposition, citing particularly its concern that NAFTA might cause meat-packing jobs to move from the United States to Mexico.

One interesting aspect of the letters received by the Senate committee is that supporters tended to identify fewer specifics than opponents. There were an average of 3.86 and 5.47 comments per letter from those providing strong support or support, respectively, compared to 7.41 and 7.88 from those opposed and strongly opposed. Supporters also tended to be less focused on their perceptions of benefits than opponents were on their concerns. Among respondents providing strong support, an average of almost 80 percent of the comments were expressions of benefits. This share dropped to 46 percent among respondents providing support. In contrast, essentially all of the comments of respondents expressing opposition or strong opposition were objections to the agreement.

To summarize the positions of agricultural interest groups at the conclusion of the NAFTA negotiations, there was widespread support for the agreement among the AFBF and other market-oriented general-membership farm organizations, from most export-oriented producer groups for grains, oilseeds, livestock, and some horticultural products, from many food processors and suppliers, and, among the sectors protected by import quotas, within the dairy and cotton industries. Opposition was expressed by general-membership organizations such as the NFU that favor domestic supply controls and labor unions. Wheat producers withheld support in an effort to obtain leverage on Canadian export issues, while producers and processors of peanuts, sugar, winter vege-

5. The classification of the responses is based on analysis of their content by the author and does not represent the view of the Senate committee or its staff. A summary of the individual survey responses is available on request. 
tables, and citrus and other winter fruits expressed opposition to specific provisions of the agreement.

\subsection{Side-Agreements and Implementing Legislation}

After the November 1992 elections, the Clinton administration followed through on its campaign pledge not to reopen negotiations on the original NAFTA text but to negotiate supplemental (side) agreements with respect to the environment, labor, and import surges. The administration worked closely with a coalition of private organizations during the negotiations for the environmental side-agreement and won the endorsement of NAFTA by seven of the principal groups. The negotiations on the labor side-agreement were less ambitious than the negotiations on the environment and did not satisfy the concerns of organized labor nor its principal supporters in Congress. The AFLCIO had essentially indicated it would oppose NAFTA regardless of the outcome of the side-negotiations and subsequently declared its continued intent to defeat the NAFTA implementing legislation in the House of Representatives.

The side-agreement on import surges provided an opportunity to address the concerns of the various agricultural producer interests. The sugar producers, in particular, had found a receptive audience in the new administration. One key Capitol Hill staff person expressed the view that the Bush administration had done poorly on the initial agreement for agriculture, especially for sugar. This concern was quickly recognized by the designated USTR, Mickey Kantor. As early as his January 1993 preconfirmation hearings, he pointed out that the side-agreement on import surges would "affect agriculture and particularly be protective, we hope, of the sugar industry, if such a surge should take place" (U.S. Congress, Senate 1993).

Despite this expressed interest in providing strengthened protection, the side-agreement negotiated by the Clinton administration only established a consultative process to consider issues related to the original NAFTA emergency action provisions. While this process could expedite subsequent consideration of industry injury claims, the side-agreement did not address the types of changes sought in other initial provisions of NAFTA by the agricultural producer groups.

As the negotiations for the three side-agreements carried into the late summer of 1993, the Clinton administration withheld active support for NAFTA pending their conclusion. Internal debate continued within the administration over the level of priority to place on the passage of NAFTA. In the meantime, between the signing of the initial agreement in December 1992 and completion of the side-agreements in August 1993, increased opposition to NAFTA was articulated by individuals and groups that included some of the Democratic leadership of Congress, the AFL-CIO, third-party presidential aspirant Ross Perot, some environmental, civil rights, and consumer groups, and conservatives such as Pat Buchanan and others. 
A setback for supporters of NAFTA came on June 30 when a federal district judge ruled that its implementation required an environmental impact statement. This ruling could have indefinitely delayed consideration of the agreement by Congress.

A subsequent low point for NAFTA supporters came after the congressional recess in August. Many members of Congress were bombarded by the vocal opposition to NAFTA by Ross Perot's backers and others within their districts. Crucial Republican support for the agreement seemed to be slipping. One high-ranking member of the White House NAFTA task force observed that the Perot people had done to Republican support for NAFTA what organized labor had done to the support among Democrats.

In this setting, President Clinton used the September 13, 1993, signing ceremony for the side-agreements to launch an intense campaign for implementation of the agreement. The ruling that NAFTA required an environmental impact statement was overturned on September 24 by a unanimous decision of the U.S. Court of Appeals. The Clinton administration then proceeded with efforts to build a broad public case for the benefits of NAFTA and to pursue the necessary votes in Congress "one or two and five or ten at a time." Agricultural interest groups played a role in each of these strategies.

\subsubsection{Ag for NAFTA and the Citizens Trade Campaign}

When it became apparent that NAFTA was in trouble in Congress, several of the agricultural groups began to consider ways of making a more visible show of support. Their perception early in the summer was that agriculture was viewed as divided on NAFTA, not as an industry that would benefit. Five groups-the AFBF, the NCGA, the NCA, the National Pork Producers Council, and Farmland Industries-formed an umbrella support organization called "Ag for NAFTA." Membership was open to any agricultural group willing to add its name with no financial or other commitments required. Ag for NAFTA lent its support to the broader proagreement coalition USA*NAFTA but remained separate in its financing, organizing, and activities.

The perception of the Ag for NAFTA organizers was that the Clinton administration was "hungry for support" since there was little grass-roots effort developing in favor of the agreement. Ag for NAFTA brought 150 farm representatives to Washington at the end of July and sponsored a variety of publicity activities. The staff person responsible for spearheading Ag for NAFTA expressed the view that these activities (including press conferences at the House of Representatives and with USTR Mickey Kantor) had "completely turned around perceptions of agriculture's views" despite receiving limited coverage. He rated their success on this initial objective as "excellent." By September, Ag for NAFTA had 140 affiliated organizations.

The next objective of Ag for NAFTA was to reassure members of Congress that they had a base of support if they voted for the agreement. One hundred and seventy members were targeted for attention. The tactic was simply to try 
to insure that these members heard from their constituents in support of NAFTA at town meetings, office visits, and through the mail.

A third activity of Ag for NAFTA was to build grass-roots support for the agreement among their constituents. The organizers felt members of their own groups had been "bombarded with the opposition position" and viewed it as crucial to counter some of the opposition statements and dispel misconceptions among farmers. Supporters were encouraged to write to their newspapers, participate in radio talk shows, and take other steps to promote knowledge of the benefits of the agreement for agriculture.

Much general commentary has been directed at the total levels of expenditures by various parties in their efforts to affect the NAFTA negotiations and congressional debate (see, e.g., Grayson 1993; Lewis and Ebrahim 1993). In the context of the millions of dollars of apparent expenditures, the scale of the $\mathrm{Ag}$ for NAFTA activities was modest. The key organizer devoted about onehalf of his time to NAFTA and another staff person about one-fourth of her time. Ag for NAFTA had an initial budget of about $\$ 10,000$. The respective member organizations paid the travel expenses of participants in $\mathrm{Ag}$ for NAFTA activities, and its final budget for publicity, advertising, and other expenses was less than $\$ 100,000$.

In addition to the efforts of Ag for NAFTA, the AFBF and many of the specific commodity associations also devoted staff and resources to support passage of the NAFTA implementing legislation. Again, a typical commitment involved the assignment of one or two staff persons to preparation of informational materials and efforts to mobilize the membership to support the agreement and convey their support to the public and Congress. The representatives of these organizations widely acknowledged that their efforts would only be successful if President Clinton was fully committed.

Opponents of NAFTA also continued to mobilize around the implementing legislation. The NFU made defeat of NAFTA one of its top priorities. It was a founding member of the Citizens Trade Campaign (CTC), the umbrella group that led the opposition efforts, and provided the CTC with office space and other services. The NFU argued that supporters of NAFTA had not done the grass-roots organizing necessary to succeed and launched grass-roots efforts of its own and in conjunction with the CTC. While not formally aligned with Ross Perot, representatives of the NFU believed he had changed the media dynamics and reduced the prospects for passage of the implementing legislation.

\subsubsection{Wheat Opposition}

Continuing their break with the other export-oriented commodity groups, wheat producers held their support for NAFTA hostage to resolution of the price transparency and transportation subsidy issues with Canada. Their representatives viewed these as issues on which they would "never give up." In exchange for their support for NAFTA, the wheat producers asked the adminis- 
tration to take action under the emergency provisions of section 22 . The emergency provisions permit the secretary of agriculture to recommend immediate quotas or tariffs rather than wait for an ITC investigation and ruling. The wheat producers resisted prodding to join the coalition of NAFTA supporters unless their contentions toward Canada were addressed. A representative of the NAWG viewed as its trump card an ability to "provide a level of comfort to members on the fence who want to vote for NAFTA but need political cover." He expected "a lot of hard bargaining" before the implementing legislation was approved.

\subsubsection{Division among the Import-Quota and TRQ-Protected Commodities}

The import-quota and TRQ-protected commodities pursued the different approaches to the implementing legislation suggested by the particular circumstances of each sector. Consistent with the dairy ATAC report, the NMPF adopted a position of support for the agreement during summer 1993. Representatives of the NMPF met with Mickey Kantor to point out that it was the first section 22 group to endorse a trade agreement. They asked for his support in return for their "self-help" legislation and on favorable levels of dairy market access in the GATT Uruguay Round. The NMPF also sought support for its view that the provisions of the Canada-U.S. FTA that eliminated agricultural tariffs would apply retroactively to dairy products if Canada were to tariffy its quantitative dairy trade barriers under a GATT agreement. Such an interpretation of the language and intent of the Canada-U.S. agreement had been consistently opposed by Canadian milk producers and the Canadian negotiators.

The NCCA also endorsed NAFTA in October 1993 rather than hold out for final concessions. The producer members of the council continued to express reservations about the agreement but agreed not to oppose the processors' consensus in its favor. The NCCA made it clear, however, that it did not support the provisions of the pending GATT agreement with respect to cotton.

While dairy and cotton interests moved toward support of NAFTA, peanut producers remained opposed. Some state organizations (in particular, Georgia) were very active in opposition. Other state organizations took a less active role because they did not want to alienate Congressman de la Garza after his efforts on their behalf. The Washington lobbyist for the producers pressed ahead with efforts to influence the implementing legislation, and the producer groups kept pressure on the members of Congress from districts where they had strength. The peanut producers indicated that the intensity of their final opposition to NAFTA would depend on the assurances provided in the implementing legislation in terms of blocking transshipments, quality control, and other issues affecting access to their protected market.

Sugar industry groups were also united on opposition to NAFTA. The sugar producers made strong efforts to obtain their two modifications of the initial agreement: inclusion of corn sweeteners in determining the balance of production and consumption affecting Mexican access to the U.S. sugar market and 
a ceiling on Mexico's access for the full 15-year adjustment period. The sugar producers lobbied USDA and USTR and pressed their case through the Senate sweeteners caucus. A letter of support for the producers signed by 34 senators was given to the secretary of agriculture just prior to his consultations with the Mexican government in late August, together with separate letters of support from Senators Conrad and Dole, a letter of concern signed by ambassadors from 16 Caribbean Basin Initiative countries, and the transcript of a public meeting intended to show that the Mexican sugar industry had advised its government that it did not object to the U.S. producers' recommendations. The sugar producers were satisfied that the secretary and the USTR understood their concerns and were sympathetic to them. Nevertheless, they committed to "go hell bent to defeat NAFTA" if the agreement was not revised. On September 27 , they pledged up to $\$ 500,000$ to a campaign of opposition, indicating that their opposition would be withdrawn if their specific concerns were addressed.

The demands of the sugar sector brought into focus the competing interests of different commodity groups within U.S. agriculture and the relative strength of the Mexican and U.S. negotiating positions. The NCGA indicated that if the sugar provisions could be modified without changing the negotiated corn TRQ (2.5 MMT, compared to the 3.5 MMT the producers had sought initially), then they would not object, even though the modification would reduce the likelihood of additional demand being created by a shift to corn sweeteners in the Mexican soft drink industry. The corn growers indicated they would oppose modifying the initial sugar agreement if it involved lowering the negotiated corn TRQ.

The sugar issues were even tougher on the Mexican side. Mexico was going to give up its traditional and politically sensitive protection for corn under NAFTA and sought access to the U.S. sugar market as a potential opportunity for some of its agricultural producers. While Mexican consumer well-being would be improved by lower corn prices, more than offsetting the loss to producers, sugar prices for consumers were to rise under NAFTA if Mexico fulfilled its pledge to raise tariffs on non-NAFTA countries to the U.S. over-quota level. The opportunity to sell some of its sugar in the protected U.S. market would offset part of the cost to Mexico of adjusting to U.S. sugar policies. The Mexican negotiators had worked hard for concessions on sugar, although, as indicated in the sweeteners ATAC report and elsewhere, most participants in the negotiations agreed that the Bush administration had not resisted provisions that might put pressure on the U.S. sugar program. In any case, Mexico did not consent to modifying the sugar provisions of the initial August 1992 agreement until it became critical to do so near the end of the U.S. congressional deliberations.

\subsubsection{The Florida Coalition}

Working along commodity lines as well as through the unified position among agricultural groups within the state, the Florida coalition pressed fur- 
ther for accommodation of the concerns of sugar, winter vegetables, and citrus and other winter fruits. The fruit and vegetable producers continued to seek longer tariff phase-out periods for more commodities and price-based import surge safeguard mechanisms. They also continued to express concern about the effects on their competitiveness of disparities in environmental and labor regulations. A key citrus representative described their particular goal as "a safeguard whereby if Mexico sells below a breakeven price for Florida producers, then the tariff will snap back in place." Characterizing this as a "permanent" system, he argued for a tariff equal to the differences in costs of production between Florida and Mexico. This was the type of barrier to trade popularized under the name of a "social tariff" by Ross Perot in his highly visible anti-NAFTA campaign (Perot and Choate 1993).

The coalition of Florida agricultural producers remained central to the NAFTA debate by working closely with the state's congressional delegation. Throughout the congressional deliberations about NAFTA legislation, almost the entire Florida delegation of 10 Democrats and 13 Republicans remained on record as opposed to the agreement.

\subsection{End-Game Concessions}

As the November 17 vote on the NAFTA implementing legislation approached, the administration continued to struggle to assemble a supportive coalition. Leaders of the opposition, including Congressmen Richard Gephardt and David Bonior, the majority leader and second-ranking member of the Democratic congressional leadership, claimed to be closing in on the votes needed to defeat the legislation. Organized labor, the CTC, Ross Perot, and others pressed their opposition in public forums and congressional lobbying.

With the fate of the agreement uncertain in the House of Representatives, the agricultural commodity groups were positioned to play a significant role in the bargaining to win support for the implementing legislation. Unlike organized labor and other opponents publicly committed to defeat of the agreement in its entirety, most of the agricultural commodity groups had expressed opposition only to specific aspects of the agreement. Moreover, between the Florida delegation and the sugar, peanut, and wheat interests, a large number of congressional votes rested at least in part on satisfying the concerns of the agricultural producers.

The end game exploded into public view in early November. Concessions obtained for agriculture in the last two weeks of the debate are summarized in table 7.8 .

\subsubsection{Initial Letters and Concessions}

An initial November 3 letter from the USTR to Mexico's secretary of commerce addressed concerns of the wine industry (Office of the U.S. Trade Representative 1993). The letter indicated that the United States would seek mu- 
Table 7.8

Final NAFTA Concesslons and Assurances to Agricultural Interests

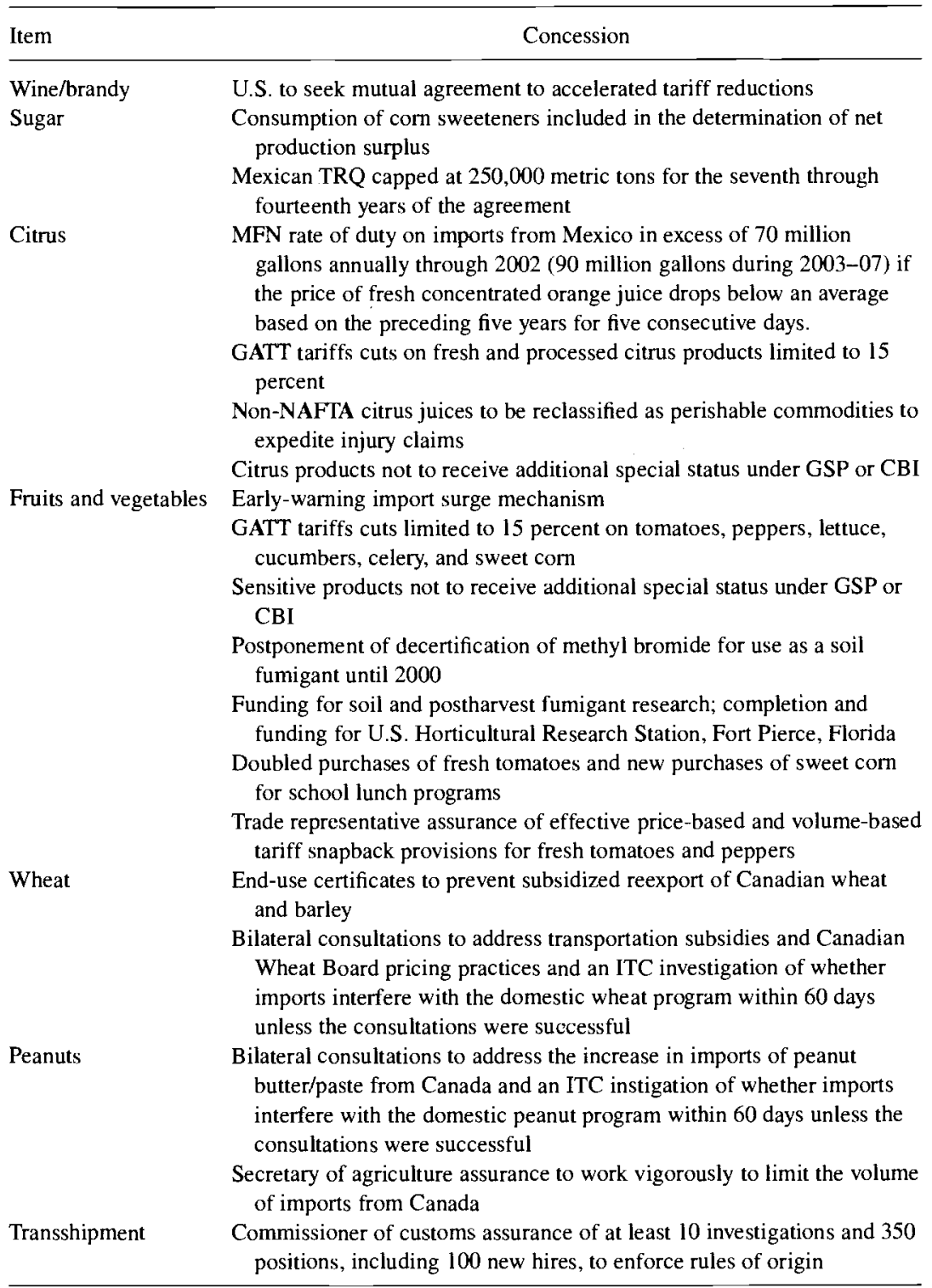

tual agreement to accelerated tariff reductions for wine and brandy (as well as flat glass, home appliances, and bedding components).

A second and more significant letter confirmed the trade representative's understanding that the two parties had agreed that substitution of corn syrup for sugar could "result in effects not intended by either Party" and that subse- 
quently they had reached an agreement that consumption of corn syrup would be included in the determination of "net production surplus." The letter also indicated an agreement had been reached that, notwithstanding previous provisions, the ceiling for Mexican sugar sales in the United States under NAFTA would be 250,000 metric tons for the seventh through fourteenth years. In short, Mexico had conceded to the demands of the U.S. sugar producers. Subsequently, the sugar industry indicated it would withdraw its opposition to NAFTA. At least a dozen votes in the House of Representatives were expected to be influenced to support the implementing legislation by the decisions of the sugar associations.

A third letter between the U.S. and Mexican negotiators addressed the issue of a price-based safeguard for citrus. The letter specified that the countries had agreed that if the U.S. price of fresh concentrated orange juice dropped below an average based on the preceding five years for five consecutive days, then the United States could apply the prevailing MFN rate of duty on imports from Mexico in excess of 70 million gallons annually through 2002 and in excess of 90 million gallons annually during 2003-07. This change provided only a modest modification of the original citrus provisions, nothing like the social tariff protection that had been called for by some representatives of the industry.

In addition to this modest change in the provisions of NAFTA, the citrus producers had bargained for other concessions from the administration. The board of directors of Florida Citrus Mutual voted to withdraw their opposition to the agreement on November 10. They announced that the association had won three additional concessions: that tariffs on all forms of fresh and processed citrus products would not be cut more than 15 percent under the pending Uruguay Round GATT agreement, that non-NAFTA citrus juices would be reclassified as perishable commodities under U.S. law (expediting future injury claims by the industry), and that no foreign citrus products would receive additional special status under the Generalized System of Preferences (GSP) or the Caribbean Basin Initiative (CBI).

As the anti-NAFTA Florida coalition collapsed and momentum was gained for passage of the implementing legislation by Congress, the other Florida fruit and vegetable producers also sought accommodation with the administration. Their representatives were not offered modifications of the agreement that required the concurrence of Mexico. Instead, they were offered a range of administrative concessions in exchange for helping deliver support for NAFTA from the Florida congressional delegation. These concessions included the use of an early-warning import surge mechanism and limits for certain commodities with respect to GATT, the GSP, and the CBI similar to those offered for citrus. They also included an environmentally controversial postponement of decertification of methyl bromide for use as a soil fumigant until 2000 and funding for research intended to "insure that Florida agriculture would continue to have access to commercially viable technologies" for soil treatment and postharvest 
fumigation (including funding for a particular horticultural research station). Finally, the administration agreed to increase purchases of fresh tomatoes and sweet corn for school lunch programs. Based on these concessions, the board of directors of the Florida Fruit and Vegetable Association announced they had voted to withdraw its opposition to NAFTA on November 11 .

\subsubsection{The Final Days}

With less than a week before the scheduled congressional vote and with leaders of the opposition still claiming they would defeat NAFTA in the House of Representatives, the administration and its supporters could not relax their efforts to obtain passage of the implementing legislation. The Ag for NAFTA coalition sponsored a "fly-in" that brought 50 to 60 leaders of various member organizations to Washington for a final round of lobbying on behalf of the agreement. They contributed to the decisions of a number of undecided representatives, but the real action was with the groups that had been or remained opposed.

The wheat producers engaged in tense late-deal bargaining. They had been able to insert into the implementing legislation a provision for end-use certificates for wheat and barley intended to counteract their use by Canada and insure that Canadian products did not receive U.S. export subsidies. However, the producers' earlier hopes for emergency section 22 import quotas were scuttled when, by several accounts, the administration determined that the wheat growers could not influence many congressional votes. The wheat producers were told "emphatically" that the administration would not take emergency section 22 action. However, the president agreed to accommodate the producers by asking the ITC to initiate a section 22 investigation in 60 days to determine whether imports from Canada were interfering with the wheat support programs of the Department of Agriculture. The ITC investigation would be undertaken unless there were successful bilateral negotiations to address Canadian policies, including "transportation subsidies and Canadian Wheat Board pricing practices." A letter from the president to this effect was sent to the ITC and several individual congressmen on November 15 . The next day, less than 36 hours before the scheduled vote in the House of Representatives, the NAWG announced it would "now work for congressional approval of NAFTA."

Partly on the basis of the wheat concessions, five congressmen, including two counted by the Associated Press as leaning against the agreement and two counted as undecided, announced their support for the implementing legislation. One of these representatives, Congressman English, was also concerned about illegal transshipment of peanuts and beef through Mexico. To address the opposition of the peanut producers and Congressman English's concerns, the president committed the administration to bilateral consultations on imports of peanut butter from Canada and to a second ITC investigation within 60 days if necessary. The secretary of agriculture assured one congressman that 
he would "work vigorously ... to limit the volume of Canadian exports of peanut butter and paste, which would include your suggestion of a cap at 1 percent of U.S. domestic consumption." Congressman English, who resigned shortly after the NAFTA vote to accept an appointment as head of the National Rural Electric Cooperative Association, was also assured by the commissioner of customs that there would be "at least ten visits to agricultural processing sites in Mexico" and that " 350 positions, including 100 newly hired employees" would be assigned to enforcement of the NAFTA rules of origin.

Final critical decisions were made by the Florida congressional delegation. It scheduled a closed-door meeting on Tuesday, November 16. An Associated Press poll had counted only five of the 23 members of the delegation as supporting or leaning toward supporting the agreement the previous day, so a large number of votes were at stake. Some of the Florida agricultural producer groups, and many of the individual producers, disagreed with the decisions of Florida Citrus Mutual and the Florida Fruit and Vegetable Association to withdraw their opposition. Moreover, the case against NAFTA had been made on numerous grounds in Florida. Not all of the state's congressional representatives seemed convinced that the accommodations offered to agriculture were sufficient for them to support the agreement.

A pivotal senior member of the Florida delegation was Representative Tom Lewis who served on the House Committee on Agriculture. To provide Congressman Lewis with assurance about his concerns required an additional letter from Mickey Kantor specifying that NAFTA contained "effective price and volume-based snapback provisions to deal with increased imports of fresh tomatoes and peppers." The next day, Congressman Lewis and 12 other members of the delegation voted with the administration. The NAFTA implementing legislation passed in the House of Representatives by a 234-200 majority.

\subsubsection{Unconfirmed Deals}

In addition to the confirmed concessions and assurances and the votes that went with them, there were rumors in the press of more insidious deal making. One rumor was that the administration would back away from its intention to raise grazing fees on federal lands from $\$ 1.86$ to $\$ 4.28$ per animal unit in exchange for support for NAFTA from 10 western congressmen. The Interior Department denied such a connection (Wall Street Journal 1993b), but the administration subsequently partially backed down and proposed raising the grazing fees to $\$ 3.96$ over three years.

It was also rumored that the $\$ 0.75$ per pack increase in the cigarette tax proposed to finance health care reform might be scaled back in exchange for support for NAFTA. The administration denied such a deal but two North Carolina Democrats, Charles Rose and Steve Neal, who had previously been opposed or leaning toward opposition ended up voting in favor of the implementing legislation after several meetings with House Ways and Means Committee Chairman Dan Rostenkowski. Congressman Neal denied his vote on NAFTA 
had anything to do with the tobacco tax, and Congressman Rose, while vague, acknowledged that the president had not promised him anything (Wall Street Journal 1993a). The $\$ 0.75$ tax was subsequently included in the president's proposed 1995 budget.

In the context of these rumors of possible deal making on issues not directly related to trade, it is of interest that one possible deal never seemed to be under consideration. Concurrent with the NAFTA debate, the administration was engaged in court-ordered discussions with Florida sugar and fruit and vegetable producers seeking an out-of-court settlement on a program to restore the Everglades. At issue were how to purge agricultural runoff of phosphorous and other chemicals and who would pay the costs of such efforts. The producers had agreed to take some land out of production to create filtration marshes, but the talks broke down in December 1993 over their demands for strong assurances on the limits of their future obligations. Despite the importance of the Florida delegation in the NAFTA debate, there was no linkage of the NAFTA vote to this environmental negotiation. ${ }^{6}$

\subsection{Conclusions from the NAFTA Outcomes}

In drawing inferences about the political economy of trade protection on the basis of the participation of various agricultural groups in the NAFTA negotiations and the congressional debate over its implementing legislation, a crucial issue is the extent to which the process provided a mechanism for overcoming established protection among agricultural sectors and expanding international markets. The NAFTA outcomes highlight the dual character of international negotiations that Putman (1988) has referred to as a simultaneous two-level game. At one level, a framework has to be established for a mutually acceptable international agreement. At a second level, any such agreement must be ratified within the domestic political processes of the negotiating partners.

In the case of NAFTA, President Salinas and President Bush articulated support for comprehensive liberalization of trade between Mexico and the United States. The high-level decision to include all agricultural products under provisions for long-run trade liberalization was endorsed by the Mexican side, within a relatively autocratic decision-making structure, and by some U.S. agricultural interests.

The decision to achieve liberalization of agricultural trade in the long run accomplished bilaterally one of the goals of the original U.S. zero-option GATT proposal and established a strong objective for the NAFTA negotiations, especially compared to the relatively weak provisions for agriculture in previous trade agreements and the significant weakening of the zero option in

6. There was some discussion within the sugar industry of linking the two issues, but it was concluded that it would be infeasible to do so. 
the final Uruguay Round GATT agreement. ${ }^{7}$ For this reason, the provisions for agriculture negotiated between Mexico and the United States may deserve the "A" grade received from Hufbauer and Schott (1993) in their NAFTA evaluation. However, Canada resisted participating in an agreement of such broad scope for agriculture. Those interests in the negotiations that favored trade liberalization lacked sufficient influence to force Canadian concessions. Instead, they had to settle for extension of the less-comprehensive bilateral agricultural market access provisions of the previous Canada-U.S. FTA and a similar agreement between Mexico and Canada.

Once the broad direction of the NAFTA negotiations was set, the domestic political process provided multiple points of access for interest groups in the United States to influence specific provisions of the agreement. The politically palatable but conflicting principles that expanded export opportunities were desirable but that imports should not cause too much disruption of domestic industries guided the negotiations toward the tariffication of quantitative import restrictions, with limited initial TRQs, high initial over-quota tariffs, and long transition periods for expanding market access and reducing tariff levels. Agricultural producer groups were faced with either seeking concessions related to the parameters of the adjustment mechanisms or simply opposing the agreement. Few of the agricultural groups chose outright opposition. Rather, they acquiesced to the Bush and, subsequently, Clinton administrations' support for the long-term objectives of the agreement but sought modifications of specific adjustment provisions.

From the efforts made on NAFTA by interest groups within agriculture and more widely, it is apparent that both groups that anticipated gains and those trying to avoid expected losses were involved in the decision-making process. At the risk of oversimplification, the stakes for various agricultural interest groups and the levels of their participation in the process are summarized in table 7.9. Rational behavior might be hypothesized to result in all groups falling on the main diagonal of the table, with their positions and activity levels correlated with the likely economic impacts.

To a large extent, agricultural interest group responses to NAFTA were consistent with its estimated economic impacts. The signs of these impacts, together with various nonquantified related issues (particularly extension of

7. The final GATT agreement replaced quantitative restrictions (including all U.S. section 22 quotas) with TRQs and high over-quota tariffs on a multilateral basis. However, the GATT agreement only requires minimal market access of 5 percent of consumption under TRQs and reductions of over-quota tariffs by an average of 36 percent ( 15 percent minimum) after six years. The effectiveness of the over-quota tariff cuts on improving market access will depend on the levels from which the cuts are made, and there is a strong possibility that the tariff equivalents of many quantitative restrictions were inflated. The final GATT agreement also places some limits on domestic support payments, unless they are decoupled from production levels, and constrains export subsidies. The U.S. implementing legislation stipulates that sugar imports from Mexico will be included in, not additional to, its global TRQ commitment. 
Table 7.9 Summary of the Economic Stakes and the Activities of Interest Groups

\begin{tabular}{|c|c|c|c|c|}
\hline \multirow[b]{2}{*}{ Economic Stakes } & \multicolumn{4}{|c|}{ Activity Level } \\
\hline & Strong Support & Support & Opposition & Strong Opposition \\
\hline Positive & $\begin{array}{l}\text { Corn } \\
\text { Livestock }\end{array}$ & & & \\
\hline Modestly positive & $\begin{array}{l}\text { Processing } \\
\text { industries }\end{array}$ & $\begin{array}{l}\text { Feed grains } \\
\text { Oilseeds } \\
\text { Dairy } \\
\text { Cotton }\end{array}$ & & Wheat \\
\hline Modestly negative & & & & $\begin{array}{l}\text { Sugar } \\
\text { Peanuts } \\
\text { Florida fruits and } \\
\quad \text { vegetables }\end{array}$ \\
\hline
\end{tabular}

NAFTA to other countries), rather than the magnitude of the direct impacts often seemed important determinants of interest group behavior. Accounting for some of the related issues brings a closer correlation of the economic interests of some of the groups and their roles in the NAFTA process than is initially evident.

Given the different responses to NAFTA among agricultural interest groups, questions arise concerning the avenues of influence they utilized to affect the negotiated agreement or obtain subsequent concessions. A wide range of options were available, and groups generally participated in the process in a variety of ways. A reasonable generalization is that groups that found the broad outline of the negotiations amenable to their interests were able to work closely with the negotiators and their technical staffs, and some path toward liberalized trade was achieved. Interest groups objecting to the general direction of the negotiations sought redress through Congress.

Too much can be made, however, of the choice by interest groups among avenues of influence on purely institutional grounds. Despite the broad commitment to the trade agreement by both the Bush and Clinton administrations, receptivity to the interests of specific groups changed after the 1992 election. In particular, support for the sugar program is usually identified with the Democratic party, and the tension between sugar producer groups and the trade negotiators during the Bush administration is not disputed by participants in the process. The Clinton administration signaled very early that it was more receptive to the concerns of the sugar sector, and this receptivity was reflected in the executive branch. Likewise, wheat producers did not expect much support from the executive branch when a Republican administration was in power. Thus, even with bipartisan support for NAFTA, there was a partisan aspect to the avenues that were effective for specific commodity groups.

More generally, there is a widespread supposition that interest groups likely 
to benefit from expanded export opportunities have difficulty becoming as organized on their own behalf as interests likely to face increased competition (with reference to agriculture, see, e.g., McCalla 1993). This supposition is confirmed by various aspects of the agricultural interest groups' activities on NAFTA. These aspects include the relative attention to NAFTA in different agricultural magazines, the frequency of congressional testimonies by supporters and opponents, the observations of participants on the degree to which potential losses motivated commodity group involvement, the intensity of the opponents' responses to the survey by the Senate Committee on Agriculture, Nutrition and Forestry, the resources committed to the debate over the implementing legislation by various producer groups, and the ability of the various groups to mobilize their supporters.

Another set of questions related to the activities of specific interest groups pertains to unanimity of the sectors seeking liberalization or protection. In the case of NAFTA, the strongest coalition to emerge naturally was the geographic coalition in Florida. The key members of the coalition were sugar, winter vegetables, and citrus and other winter fruits. The Florida coalition had a strong presence during the negotiations and legislative deliberations, but its unanimity broke down in the final days of the congressional debate. Sugar was the most protected of the commodities in the coalition. Florida sugar producers, acting in unison with the sugar industry in other parts of the country, were able to strike their own deal with the Clinton administration and obtain substantial concessions. The other Florida commodities receive less protection than sugar. The producers of these commodities had no similar natural allies elsewhere and were less successful in their bargaining. Thus, the Florida coalition was only partially helpful in obtaining concessions for its member groups.

Some other coalitions that might have emerged during the NAFTA process were not evident among either export-oriented or import-competing interests. Notwithstanding the efforts of Ag for NAFTA, the divisions among the general-membership farm organizations precluded a united approach for the likely exporters. Among the grains, wheat had idiosyncratic issues that affected its approach to the negotiations and even some corn growers opposed the agreement. Among the import-competing commodities, the specifics of NAFTA looked favorable to the dairy and cotton sectors but not to the peanut and sugar sectors. Issue can be taken with the analyses of particular commodity groups, as in the case, for example, of USDA's Office of Economics with the opposition expressed by peanut producers, but the point remains that the interest group perceptions precluded formation of coalitions. Issues extending beyond NAFTA were particularly important in this regard. The dairy sector apparently anticipated better medium-term opportunities in world markets (or simply more success in obtaining export subsidies) than the peanut or sugar sectors, which face numerous pressures for greater foreign access to their domestic markets.

A second aspect to the unanimity issues concerns groups other than produc- 
ers that might benefit from trade or be harmed by protection. The sugar producers were opposed by the industrial sweetener users, but as in many previous policy decisions, the sweetener users were not very effective. Other processing and supply industries also supported NAFTA. The Food Marketing Institute and others among these industries argued that the agreement would benefit consumers through lower prices. The general public did not express a strong position in terms of consumer prices but was heard from in terms of environmental issues, labor issues, and overall political support for NAFTA. The proportion of the public favoring the agreement increased as the congressional vote approached but remained less than 50 percent by most late polls.

A reason for some optimism in this context is that the final efforts to win support for NAFTA were successful. A bipartisan coalition, of which agricultural interests were only a small part, was marshalled to make the case for the agreement. The broad challenge to its leadership by the AFL-CIO, Ross Perot, and others was defeated. Thus, the danger that the United States would turn conspicuously inward on an important economic and foreign policy decision was held at bay in a post-Cold War setting. In this regard, the disadvantages NAFTA created for Japan and the Europeans were unfortunately often touted as an argument. This theme undermines efforts to liberalize trade on a multilateral basis, quite to the contrary of the intent of the original consideration of bilateral agreements in the early 1980s.

For agriculture, despite the apparent inability of the export-oriented interests to become as well organized in their own behalf as the import-competing interests, and despite the grueling congressional NAFTA debate and the associated bargaining and concessions, the original provisions of NAFTA that eliminate trade barriers between Mexico and the United States in the long run remain largely intact. A careful examination also suggests that many of the concessions and assurances offered to U.S. agricultural interest groups to secure votes for the implementing legislation weaken the original NAFTA transition period provisions only marginally. Other acknowledged concessions to the interest groups are also relatively minor.

This said, the notion that a trade agreement can serve as a channel for reform of entrenched domestic U.S. agricultural programs fared poorly under NAFTA. Among the protected commodities, dairy and cotton came to support the agreement only when strong rules of origin were adopted and the absence of any threat to their domestic markets became apparent. They conceded nothing generally about the protection they receive. Peanut producers fought hard against the agreement and battled in the end for concessions to sustain their protection.

More egregious than the dairy and peanut provisions of the agreement, among its trade-distorting effects NAFTA initially created a common sugar market between Mexico and the United States from which both Mexican and U.S. producers were potentially going to benefit at the expense of consumers and excluded producers. The subsequent concessions to U.S. sugar interests, 
which helped deliver over a dozen congressional votes, exacerbated the initial distortion by essentially stealing from the Mexican producers some of their potential market opportunity while enhancing the potential demand facing U.S. producers. It was an impressive show of strength by the U.S. sugar industry. The concessions obtained gutted the agreement for freer bilateral trade, albeit within a protected common market, for at least the next 15 years. They also raise the question of whether the agreement to allow unrestricted trade in sugar between Mexico and the United States after 15 years is ultimately credible.

The differences in the NAFTA outcomes between Mexico and Canada are also telling. The U.S. producer groups were most successful with respect to Mexico, which agreed to open itself to much more competition from U.S. agricultural products than did the United States to competition from Mexican products. Reducing trade barriers is good policy for Mexico overall, but Mexican agricultural producer groups that might have supported a stronger agreement in terms of their own export opportunities had limited ability to influence the negotiations. Nor was there much countervailing power to the pressure of import-protected U.S. agricultural producers for concessions. To insure NAFTA's approval, the U.S. government succeeded in pressing these concessions on the Mexican government.

It remains uncertain exactly how Mexico will fulfill its NAFTA commitments on agriculture. Facilitating trade liberalization with transfer payments to its affected producers as part of the reform of its domestic agricultural policy may result in the anticipated increase in trade. But in light of the political rebellion launched in the southern state of Chiapas on the day NAFTA went into effect, and the subsequent assassination of the presidential candidate of the Institutional Revolutionary Party (PRI) in March 1994, it also remains possible that Mexico will utilize its support policies to stimulate its domestic agriculture. No limits were set on domestic support levels under NAFTA and, while the GATT agreement subsequently imposed some constraints, such a policy reversal could dampen U.S. export prospects compared to the expectations of some producer groups. ${ }^{8}$

With Canada, the story is different. Throughout the NAFTA process, importcompeting Canadian agricultural producers were more effective in defending their established protection than the Mexican producers. Canada's participation in the agreement was largely ignored in the United States except by a few special interests. But to insure passage of the NAFTA implementing legislation, the Clinton administration made unilateral promises to several U.S. agricultural commodity groups about their perceived grievances over imports

8. Alma Guillermoprieto (1994) relates the story of a July 1994 preelection campaign rally at which President Salinas distributed the first of close to four million checks providing direct income subsidies to campesinos. "And what are you going to do with the money?" Salinas asked rhetorically. "Buy a tractor? Very good! Buy fertilizer? Excellent!" 
from Canada. Thus, one outcome of the process was that it prolonged disputes between the United States and Canada over wheat, peanut butter, and other products.

Given the focus on Mexico in the public NAFTA debate, the unresolved issues with Canada were a surprising outcome. Subsequent to NAFTA's enactment, the United States offered to settle the agricultural trade disputes with Canada by adopting bilateral free trade in agricultural products. This offer was declined, and the United States then imposed a TRQ on peanut butter under the GATT agreement. This satisfied the domestic producer interests, and they withdrew their request for an ITC investigation. For wheat, GATT ruled out establishing a permanent TRQ. The ITC issued a divided report (USITC 1994) on whether trade barriers were warranted under section 22 provisions that were, in any event, scheduled to expire when GATT took effect. After intense negotiations, Canada then agreed to temporary bilateral trade restrictions. On both counts, post-NAFTA agricultural trade between the United States and Canada ends up more laden with barriers than before.

On a somewhat different theme, the bargaining power agricultural groups held toward the end of the NAFTA debate is striking. The agricultural interest groups positioned themselves to bargain for concessions because they sought modifications of specific provisions but did not explicitly oppose the entire agreement. The concerns of the Florida coalition, sugar, peanuts, or wheat mattered to the outcome of close to 30 congressional votes.

The question that arises is why other groups did not do more to put themselves in such a position. The concessions made to agriculture toward the end of the debate were not the only concessions offered by the Clinton administration. One wonders, for example, why the AFL-CIO did not approach the president with concerns about specific industries and to seek additional transitionperiod protection in these areas in exchange for delivering their support for the agreement. One can imagine a very different coalition having been put together to pass the implementing legislation in such circumstances. Agricultural interests could have found themselves irrelevant to the congressional vote and the sugar and wheat producers sent away to make their case in another context. Curiously, one doubts these parties to last-minute concessions were the intended beneficiaries of organized labor's political efforts.

Consideration of possible alternative coalitions in support of NAFTA also raises the question of whether one-by-one bilateral negotiations offer any realistic hope for reducing agricultural or other trade barriers on an extensive (eventually global) basis. Though free trade zones are proliferating, the lesson from NAFTA seems discouraging. For each agreement one can imagine the various specific interest groups lining up in different arrays. Favoring trade liberalization when it is to their advantage, these interest groups lobby equally strongly for benefits that come from introducing policy distortions rather than removing them. On these shifting sands, negotiating multiple FTAs and building coalitions in their support looks like it leads to drudging trench warfare. 
For agriculture, in particular, attaining freer trade with Mexico under NAFTA accomplished only a small percentage of the goals sought eventually through GATT. Progress to be sure, but at such a rate as perhaps to be negligible unless the agreement with Mexico becomes a prototype for multilateral trade liberalization in the long run. This is the outcome that protected agricultural interests claim to fear but so far have avoided.

\section{References}

Agricultural Policy Advisory Committee. 1992. Report on the North American Free Trade Agreement. Washington, D.C.: Office of the U.S. Trade Representative.

ATACs (Agricultural Technical Advisory Committees). 1992. Reports on the North American Free Trade Agreement. Washington, D.C.: Office of the U.S. Trade Representative.

Barr, James C. 1993. Testimony on the Dairy Budget Reconciliation and Self-Help Initiative Act of 1993 before the Subcommittee on Livestock, Committee on Agriculture, U.S. House of Representatives. Arlington, Va.: National Milk Producers Federation.

Fruits and Vegetables Agricultural Technical Advisory Committee. 1990. Statement on issues in the NAFTA negotiations. Washington, D.C.: Office of the U.S. Trade Representative.

Gardner, Bruce L. 1987. Causes of U.S. farm commodity programs. Journal of Political Economy 95:290-310.

Gillon, William A. 1992. Letter to Jules Katz, deputy U.S. trade representative. Washington, D.C.: National Cotton Council of America.

Grayson, George W. 1993. The North American Free Trade Agreement. Headliner Series no. 299. New York: Foreign Policy Association.

Grennes, Thomas. 1993. Toward a more open agriculture in North America. In Assessing NAFTA: A trinational analysis, ed. Steven Globerman and Michael Walker. Vancouver, B.C.: Fraser Institute.

Grennes, Thomas, and Barry Krissoff. 1993. Agricultural trade in a North American Free Trade Agreement. World Economy 16:483-502.

Guillermoprieto, Alma. 1994. The only way to win? New Yorker, August 15, 32-37.

Hufbauer, Gary Clyde, and Jeffrey J. Schott. 1993. NAFTA: An assessment. Washington, D.C.: Institute for International Economics.

Krueger, Anne. 1993. Free trade agreements as protectionist devices: Rules of origin. NBER Working Paper no. 4352. Cambridge, Mass.: National Bureau of Economic Research.

Lewis, Charles, and Margaret Ebrahim. 1993. Can Mexico and big business USA buy NAFTA? Nation, 826-39.

McCalla, Alex F. 1993. Agricultural trade liberalization: The ever elusive grail. American Journal of Agricultural Economics 75:1102-12.

Miner, William M. 1993. Agricultural trade under the klieg lights: Domestic pressures and bilateral frictions. Ottawa: Carleton University, Center for Trade Policy and Law.

Office of the U.S. Trade Representative. 1993. Letters from administration officials prepared in connection with the NAFTA debate. Transmitted to the Senate Committee on Finance. Washington, D.C.: Office of the U.S. Trade Representative. 
Perot, Ross H., and Pat Choate. 1993. Save your job, save our country: Why NAFTA must be stopped-now! New York: Hyperion.

Putman, Robert D. 1988. Diplomacy and domestic politics: The logic of two-level games. International Organization 42:427-60.

Sanderson, Fred H. 1994. The GATT agreement on agriculture. Washington, D.C.: National Center for Food and Agricultural Policy.

Swinnen, Jo, and Frans A. van der Zee. 1993. The political economy of agricultural policies: A survey. European Review of Agricultural Economics 25:261-90.

U.S. Congress. House. 1993. North American Free Trade Agreement, Supplemental agreements and additional documents. 103d Cong., 1st sess., H. Doc. 103-160. Washington, D.C.: Government Printing Office.

U.S. Congress. Senate. Committee on Finance. 1993. Hearings on the anticipated nomination of Mickey Kantor, U.S. trade representative designate. 103d Cong., 1 st sess., S. Hrg. 103-12. Washington, D.C.: Government Printing Office.

USDA (U.S. Department of Agriculture). 1992a. NAFTA side-by-side tariff schedule. Washington, D.C.: USDA, Foreign Agricultural Service.

- 1992b. North American Free Trade Agreement: U.S. nontariff barrier offer. Washington, D.C.: USDA, Foreign Agricultural Service.

- 1993. Effects of the North American Free Trade Agreement on U.S. agricultural commodities. Washington, D.C.: USDA, Office of Economics, March.

1994. Estimates of producer subsidy equivalents and consumer subsidy equivalents: Government intervention in agriculture, 1982-1992. Statistical Bulletin no. 913. Washington, D.C.: USDA, Economic Research Service.

USITC (U.S. International Trade Commission). 1993. Potential impact on the U.S. economy and selected industries of the North American Free-Trade Agreement. USITC Publication no. 2596. Washington, D.C.: U.S. International Trade Commission.

- 1994. Wheat, wheat flour and semolina. USITC Publication no. 2794. Washington, D.C.: U.S. International Trade Commission.

Wall Street Journal. 1993a. Anatomy of a victory: "Deals"'and sense of Clinton's commitment clinched NAFTA. November 19.

1993b. White House hopes to trade changes in grazing-fee plan for NAFTA support. November 10.

\section{Comment Robert Paarlberg}

David Orden has done a clean and careful job of reconstructing the U.S. side of the agricultural component of the North American Free Trade Agreement (NAFTA). I am in strong agreement with most of his judgments, especially near the end of the paper, but there are some shades of difference along the way.

Orden starts by implying that the agricultural component of NAFTA was a victory for free trade, perhaps more so than the Uruguay Round, because NAFTA successfully embraced the original Uruguay Round concept of phasing out all border protection. I would suggest toning down this assertion. In its

Robert Paarlberg is professor of political science at Wellesley College and associate at the Harvard University Center for International Affairs. 
agricultural component, NAFTA did significantly liberalize some important import-competing sectors on the Mexican side (especially corn), but it did nothing to eliminate some important existing distortions on the U.S. side. In corn markets, while Mexican growers will lose their tariffs and import licenses, U.S. growers will not lose their target prices and deficiency payments (a domestic measure which nonetheless functions in part like an export subsidy). In corn markets, this was unilateral disarmament for Mexico.

And most conspicuously, NAFTA did not significantly liberalize U.S. sugar policy. Instead, it just extended the highly illiberal pricing regime created by that policy to sugar producers in Mexico (by raising Mexico's tariffs to the over-quota U.S. level). U.S. sugar growers complained about this because of fears that the eventual result in Mexico would be a replay of what had already happened in the United States: a replacement of sugar in beverages by highfructose corn sweeteners, freeing up sugar for export to the United States. Orden accurately describes these details when his analysis gets to the case of sugar, but he never quite qualifies the earlier assertion that NAFTA was a victory for nondistorting free trade.

A larger concern, however, is with the process lessons that can and cannot be drawn from this case. If the dependent variable is policy liberalization, then there is probably more to be learned on the Mexican side of NAFTA than on the U.S. side. And on the Mexican side, I suspect most of the liberalization that occurred came neither from the bargaining dynamic of the NAFTA negotiation, nor from an internal dynamic of interest group representation within Mexico. Mexico was able to liberalize agriculture because the Mexican government is an authoritarian one-party presidential state. Even before the NAFTA agreement, President Salinas (and his mostly nonaccountable technocratic advisers) had decided to shift Mexican agriculture out of low-value maize production and into higher-value fruit and vegetable crops. Salinas was able to do this without much concern about opposition, within the system, from Mexico's own corn producers because the Mexican government operates top down rather than bottom up (a surprising expression of opposition came later from outside of the political system, with the January 1, 1994, Zapatista uprising).

Probably the most useful process lesson drawn by Orden at the U.S. end is his observation that agricultural interest groups gained influence for the paradoxical reason that they were neither for the agreement in principle, nor opposed in principle, a stance which made them worth courting with sidepayments. The ability of farm groups to pursue commodity-specific sidepayments in this fashion, outside of the confines of the normal farm bill process, deserves more attention. Sugar producers set the standard in 1981 when they held up that year's budget process for a revived domestic sugar program. Orden's paper shows how wheat growers were able to use the NAFTA vote on Mexico to gain additional concessions in their running trade disputes with Canada. And the paper by Bruce Gardner in this volume (chap. 6) shows how 
one or two wheat-state senators were able to use a 1985 Senate budget resolution vote to get a $\$ 2$ billion Export Enhancement Program.

The political lesson would seem to be an almost impossible one to apply: liberal-minded presidents should do their best to avoid large, make-or-break, close votes in Congress. In winning such votes, the president can easily end up giving away more than he gains. 